\title{
THE STIPITATE HYDNUMS OF NOVA SCOTIA
}

$1,+1+1,+m$ $\begin{array}{ll}\text { Agriculture } & \text { Canadian Agriculture Library } \\ \text { Canada } & \text { Bibliothèque canadienne de l'agriculture } \\ \text { Ottawa K1A OC5 }\end{array}$

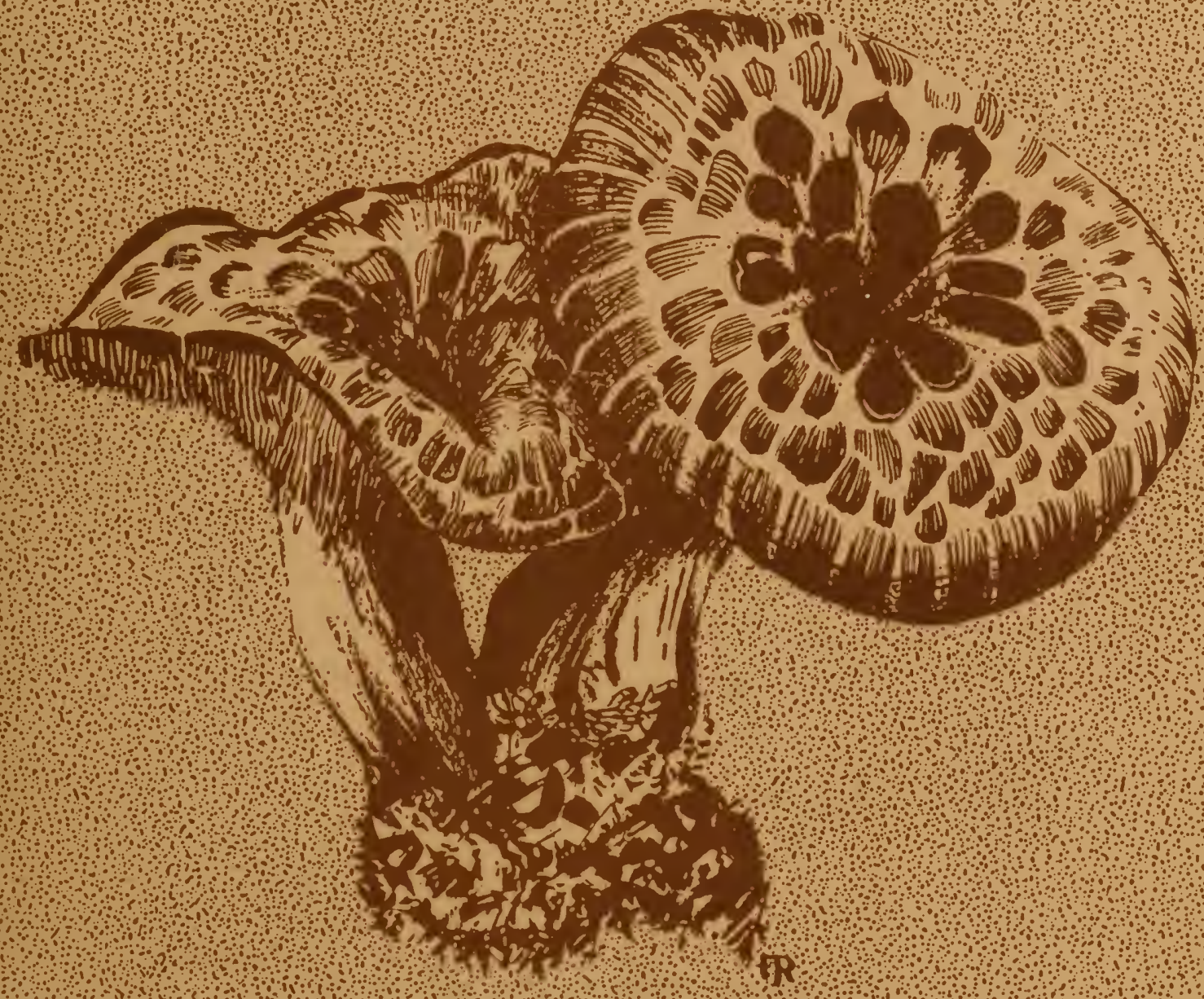

630.4

C212

P 1099

1961

c. 3 
Digitized by the Internet Archive in 2012 with funding from

Agriculture and Agri-Food Canada - Agriculture et Agroalimentaire Canada 


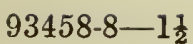





\section{THE STIPITATE HYDNUMS}

OF NOVA SCOTIA 



\title{
THE STIPITATE HYDNUMS
}

\author{
OF \\ NOVA SCOTIA
}

\author{
Kenneth A. Harrison \\ Research Station, Kentville, Nova Scotia
}

\section{RESEARCH BRANCH}

CANADA DEPARTMENT OF AGRICULTURE, OTTAWA, ONTARIO 


\section{Ordering copies :}

Money orders or cheques are made payable to the Receiver General of Canada. Enclose with your order and send to

\section{Publications Branch \\ Department of Public Printing and Stationery Ottawa, Ontario}

Publisher discounts are available.

Cat. No. A53-1099

ROGER DUHAMEL, F.R.S.C.

QUEEN'S PRINTER AND CONTROLLER OF STATIONERY

OTTAWA, 1961

$11 \mathrm{C}-27626-4: 61$ 


\section{CONTENTS}

INTRODUCTION

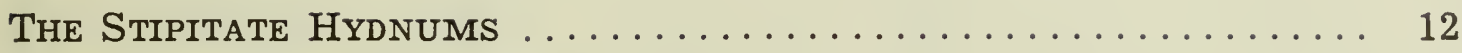

DEVELOPMENT OF THE SPOROPHORE .................. 13

INFLUENCE OF WEATHER ON THE SPOROPHORE .............. 14

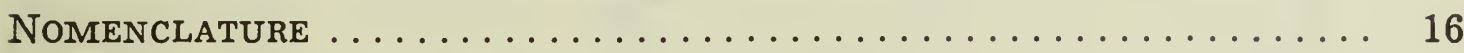

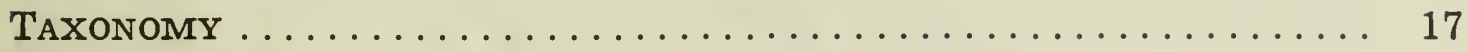

Key to the Genera of Stipitate Hydnums in Nova Scotia . . . 17

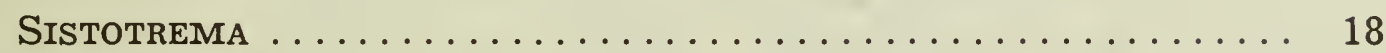

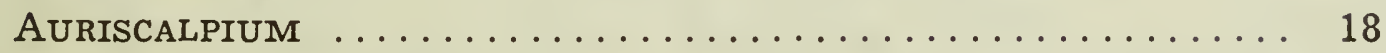

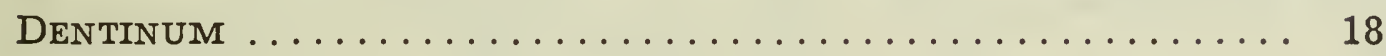

PHELlodon $\ldots \ldots \ldots \ldots \ldots \ldots \ldots \ldots \ldots \ldots \ldots \ldots \ldots \ldots \ldots \ldots \ldots \ldots$

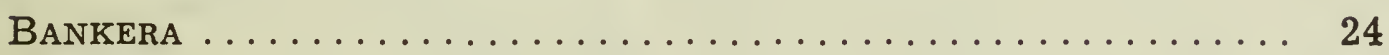

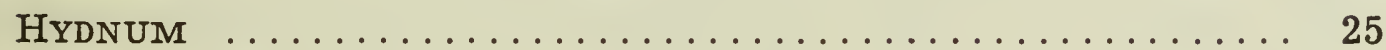

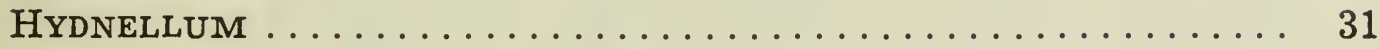

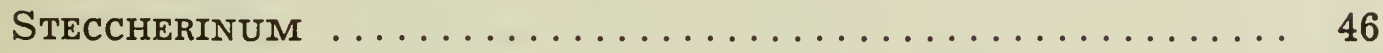

HeRICIUM $\ldots \ldots \ldots \ldots \ldots \ldots \ldots \ldots \ldots \ldots \ldots \ldots \ldots \ldots \ldots \ldots$

Acknowledgments $\ldots \ldots \ldots \ldots \ldots \ldots \ldots \ldots \ldots \ldots \ldots \ldots . \ldots . \ldots$

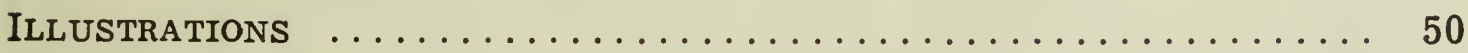

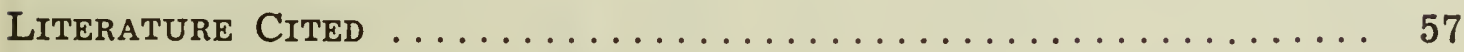

Index of Genera ANd Species $\ldots \ldots \ldots \ldots \ldots \ldots \ldots \ldots \ldots \ldots$ 


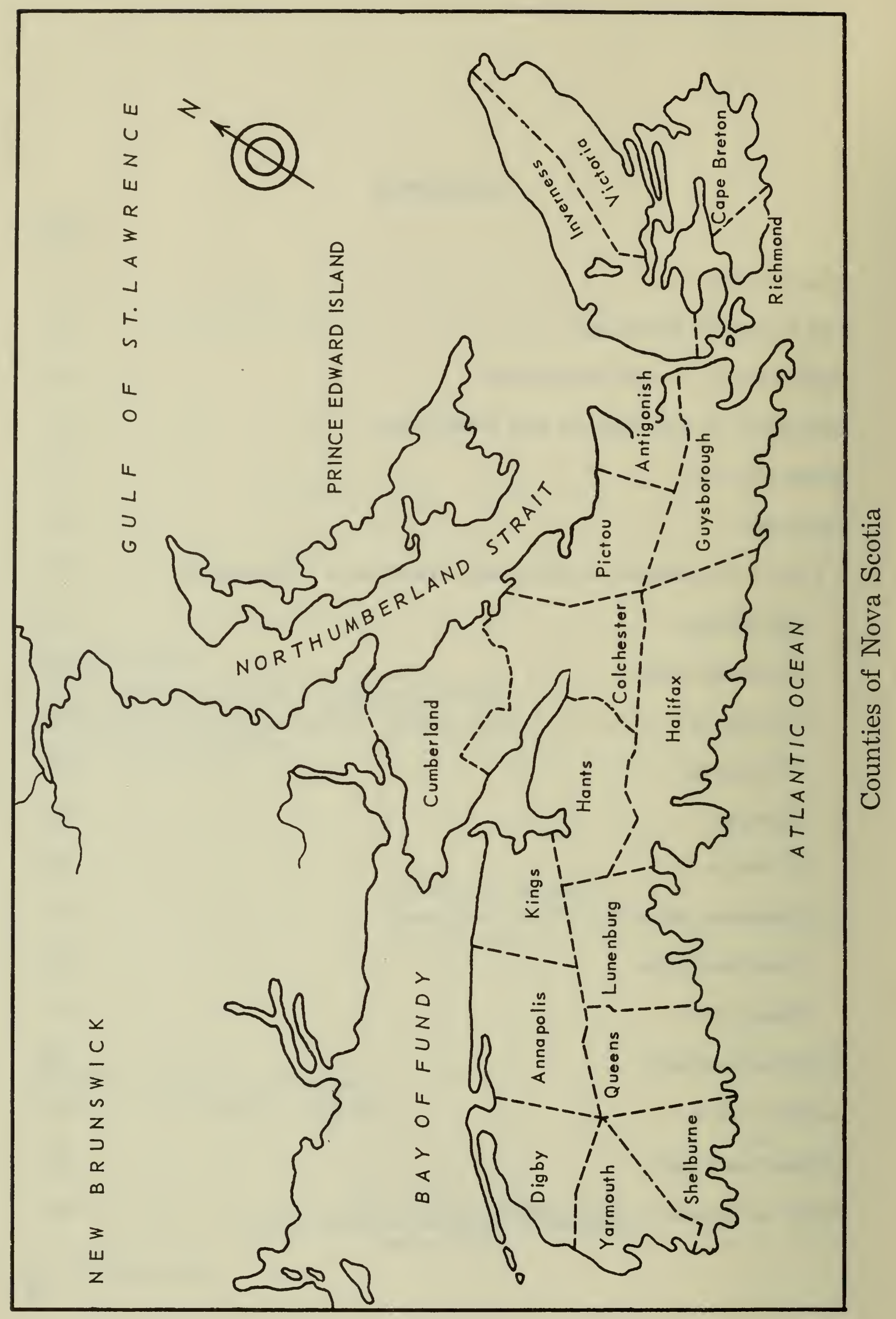




\section{Introduction}

The province of Nova Scotia, lying between the 43rd and 47 th north parallels, is made up of a peninsula and the Island of Cape Breton. Altogether it is about 340 miles long and no point is more than 30 miles from salt water. Its axis lies in a northeast-southwest direction; the Bay of Fundy, Northumberland Strait and Gulf of St. Lawrence are on the northwest and the Atlantic Ocean bounds the remaining coast line. It is joined to the mainland, New Brunswick, by the narrow Isthmus of Chignecto.

Geologically the province is an uptilted, eroded Cretaceous peneplain that is highest in the north and east and dips below the surface of the sea towards the south and west. The southern part is mostly granites, quartzites and slates, but in the northern and eastern parts there are low ranges of hills of igneous rock, syenite, diorite and granite. The principal highlands are: the North Mountain along the Bay of Fundy coast where the altitude reaches 700 feet; the Cobequid Mountains in the north just over 1,000 feet high; and the Cape Breton Highlands 1,700 feet. Interspersed with these are lowlands of Carboniferous to Triassic age which are complexes of sandstones, shales and conglomerates, and some deposits of limestone and gypsum. In addition, certain areas are overlain with glacial deposits from the recent ice ages.

The climate of Nova Scotia is maritime, being modified by air that is cooled in summer and warmed in winter by flowing in over the ocean. The province lies in the path of most of the continental storms which frequently intensify in the area before passing out to sea. Putnam (1940) has given a detailed account of the climate. The mean temperature for July, the warmest month, varies between $62^{\circ}$ and $66^{\circ} \mathrm{F}$. The number of frost-free days increases from 100 in the north to 160 in the south, and the average mean rainfall for April to October, inclusive, ranges from 18 inches along the north coast to 24 inches along the south. The average number of foggy days varies from 10 inland to 90 along the sea coast.

Botanically the province has been classified as lying in the HemlockWhite Pine-Northern Hardwood Region of eastern North America (Nichols, 1935). There is a boreal fir forest in the Cape Breton Highlands at elevations over 1,100 feet. In 1947 Roland published a flora of vascular plants of the province listing 1,323 species, and in his discussion he drew attention to the strange intermingling of species considered typical of other regions much farther north and south. The forests vary greatly and 
large areas of pure stands are rare. The native coniferous species present are red, white and black spruce, balsam fir, hemlock, larch, white and red pine and a few local areas of jack pine. The more common broadleafed trees are sugar and red maple, paper, yellow and gray birch, beech, red oak, white ash, quaking and large-toothed aspen, and willow. The hardwood stands tend to be more common in the north whereas spruce and fir are dominant in the south and eastern regions. Recent outbreaks of diseases and insects have killed many beech, yellow birch and willow trees, and their decay has furnished substrates for many fungi.

Mycologically the province has been sampled in only a few areas. The records for the province were compiled by Wehmeyer (1951), together with those from New Brunswick and Prince Edward Island in a flora of the Maritime Provinces. This included the data from his extensive collections made in Colchester County between 1927 and 1935, and those of the author between 1927 and 1940 from Kings County. Since 1950 special attention has been paid to the stipitate hydnums, and the present paper is the result of regular collections made in six selected areas within 30 miles of Kentville Research Station. Here, hydnums have been unusually abundant. Many other areas were searched each year and two special forays to the eastern end of the province have helped greatly in extending the ranges of several of the new species.

\section{The Stipitate Hydnums}

The stipitate hydnums occur most commonly on damp, well-drained, forested slopes or on slight elevations on wooded, sandy plains with high water tables. It has not been possible to establish associations with definite species of trees in Nova Scotia. These may exist, however, obscured by the similarity of the flora present in favorable collecting areas. A number of hydnums are abundant in very restricted areas and it is possible to return to such places year after year and find specimens, although these may be depauperate when the season is unfavorable for their growth. Many other species are extremely rare and have been found only once or twice over the years. Each season as new areas have been searched, some of these rarities have been found in abundance, and it has been possible to identify them with certainty.

The remarkable longevity of individual sporophores of many species and the changes in appearance that occur during the long period of their development have confused all workers studying this group. Under the favorable conditions existing in Nova Scotia, it has been possible to follow the growth of individual sporophores of some of the species at two- or three-week intervals from early August until the middle of October and the changes in color and shape have been recorded on color transparencies. In Hydnellum aurantiacum (Batsch ex Fries) Karst., for example, the 
sporophore is pure white at first but soon changes through shades of orange to rusty-brown, and completes its growth a dull, brownish-black. The shape is turbinate at first and the surface is tomentose lumpy or 'bubbly', finally becoming plane or infundibuliform with an almost glabrous, somewhat corrugated surface. Less spectacular variations occur in many other species. These 'normal' changes, in turn, are strongly influenced by rainfall and drying winds, and temperature may modify some characters by influencing the rate of growth.

\section{Development of the Sporophore}

The differences between species are often more distinctive during the younger stages of sporophore development than at any other time during their life history. The youngest stage seen in the closely gregarious and concrescent species showed a number of small processes or columns arising from a felty layer of mycelium formed beneath the surface of the duff in, for example, Hydnellum scrobiculatum (Fries) Karst., Phellodon tomentosus (Fries) Banker and P. niger (Fries) Karst. In the more widely separated and solitary forms the earliest stage found was a small mycelial tuft that develops into an ovoid column in, for example, Hydnellum caeruleum (Hornemann ex Pers.) Karst., and $H$. suaveolens (Scop. ex Fries) Karst. When still quite small the apex of the column changes in color and develops as a stipe. In $H$. suaveolens the ovoid column is violet and the apex becomes white when the stipe starts to develop. In $H$. caeruleum the ovoid column is straw-colored and the developing stipe blue.

The pileus develops from the apex of the short stipe by the growth and expansion of a blunt margin and later as a thickening of the upper surface that appears like an upwelling and a pouring over of the mycelium from the center outward. This accounts for the vase-like outline of many sporophores in immature collections. Coker and Beers (1951, p. 30) described specimens in one collection as "long-handled pestles." This type of growth is very conspicuous in the genera Hydnellum and Phellodon but is not so obvious in Hydnum, Dentinum and Bankera, where the surface is relatively smooth. The young stages of Hericium have not been studied because members of this genus are rare in Nova Scotia. A thick margin on the pileus is the usual sign that active development is taking place. The growth of the upper surface and the expansion of the cap may continue during the life of the sporophore and when two pilei of the same species touch they appear to flow together and fuse. Hydnellum geogenium (Fries) Karst., H. scrobiculatum and Phellodon tomentosus (Fries) Banker are the most outstanding examples of this type of growth. The fusion of parts is carried further in two of the new species of Hydnellum described in this paper. In these the sporophores may grow as intricate tangles of 
partly fused stipes and overlapping pilei that suggest Polyporus frondosus Dicks. ex Fries. Unfortunately these have not been found where it was possible to observe the various stages that preceded the complex hymenophore. The variations in form that exist in the stipitate hydnums often range from the simple to the extremely complex, within a single species, and add greatly to the problems of identifying the different kinds.

The initials of the spines appear as soon as there is a slight overhang to the expanding pileus. They are white in many species but the color and color variations are distinctive in others. The color soon starts to change, first at the base and then gradually along the spine toward the tip. The spines continue to grow during most of the life of the sporophore and their color will vary depending on the proportion of juvenile colored tissue at the tips and the amount of mature and maturing tissues toward the base. On mature sporophores of the various species of Hydnum and Hydnellum the spines are some shade of brown and have light-colored tips that are tinted with the color of the juvenile tissue. Part of this shade is due to the fawn-colored spores that start to mature quite early and continue to be produced during the long period of growth of the pileus.

\section{Influence of the Weather on the Sporophore}

Rainfall and humidity have a great influence on the final size and shape of the individual sporophores of each species. Development is favored by frequent light rains and high humidity; it gradually ceases during dry weather but will start again after a period of precipitation. Variations in the appearance of the sporophores of the different species depend on the manner in which growth is resumed. In Hydnellum velutinum (Fries) Karst. var. spongiosipes (Peck) Maas G., renewed growth may produce a well-defined band around the margin of the pileus with very little thickening, or it may occur over the entire upper surface, resulting in a thick turbinate sporophore. Intermittent growth can cause most puzzling variations in the sporophores; over a number of years the various collections of a single species may include specimens that range from rudiments of stipes, to clubs, vases, thin expanded pilei, stout turbinate forms, or concrescent masses.

The surface texture and color are strongly influenced by rainfall, prolonged periods of which can induce a scrobiculate type of growth on young sporophores of some species. In extreme cases, outgrowths may develop that are stipe-like and form partial pilei above the original surface. In more mature pilei, rain may only mat the tomentose surface so that it becomes relatively glabrous. The periods of rainfall or high humidity also appear to be responsible for the variously colored zones in the flesh and stipe of such species as Hydnellum aurantiacum, H. suaveolens, $H$. caeruleum, and possibly in all species in which faint zones are 
seen. Late in the season, occasional sporophores of species such as $H$. mirabile (Fries) Karst. and $H$. caeruleum are found in which the center apparently has been drowned and has started to decay.

A very interesting and rather rare character of some hydnums is the formation of droplets of colored liquid on the actively growing pilei during periods of high humidity. Red drops have been observed on Hydnellum diabolus Banker, $H$. cruentum sp. nov., $H$. velutinum var. spongiosipes, $H$. peckii Banker, H. scrobiculatum; yellow drops on $H$. caeruleum and Hydnum stereosarcinon (Wehmeyer) comb. nov.; pink drops on the stipe of Hydnum lanuginosum sp. nov.; coffee-colored drops on Hydnellum mirabile, and black drops, observed once, on very young Phellodon niger (Fries) Karst. When the drops are red and abundant the appearance is very striking.

The stipitate hydnums have a number of adaptations that absorb and hold moisture. The vaselike shape of many sporophores is a natural container for water. The tomentose surface of others absorbs water readily and remains water-soaked for some time. This water-holding capacity is noticeable in the smooth, bibulous surface of Bankera fuligineo-alba (Schmidt ex Fries) Pouzar and B. carnosa (Banker) Snell, Dick \& Taussig. Phellodon niger var. niger and var. alboniger (Peck) comb. nov. have an additional method of holding water. The outer covering of the stipe is a thick felty layer of mycelium that absorbs water like a sponge and often, if squeezed when collected, it will be found to yield one or more tablespoonfuls.

The effect of temperature, other than on the rate of growth, is not so obvious. It has been observed that in cool fall weather the spines on the margin of Hydnellum aurantiacum arise in some instances from folds, ridges or rings that strongly resemble the start of tubes. In the fall of 1955 collections of Hydnum stereosarcinon showed the margins definitely poroid and much thickened. Hydnellum caeruleum develops a much deeper blue during the cool temperatures of late September. In brief, there is hardly a character that is not modified by the weather, and for this reason the younger stages of the sporophores are most important for identification. This labile variability increases the difficulty of preparing an adequate description of a species. The failure to stress the features that are least changed by regional environments undoubtedly accounts for the confusion that has arisen amongst mycologists.

One of the most dependable characters for the identification of the species has been the color of the young growing parts: the developing stipe, its covering, the surface of the young pileus, the margin of the pileus, and the young spines. Also included are the normal sequences of color changes that occur as these parts age, together with the color reactions that follow bruising. The flesh color is an important character 
in some species but unreliable in others because of variations in rainfall. Odor and taste are distinctive although it is usually impossible to describe them adequately. The context can be woody, tough, solid, brittle or fleshy, but will vary somewhat with age. The characters that vary widely and can be misleading are: shapes, sizes, and fusion of parts; surface textures; colors of mature parts and internal zonations; size, shape and length of stipe; and size and shape of spines. The color of the spore print is used for separating some genera. However, the small spores are of limited value for the identification of species within a genus. It is even difficult to determine the average size of the spores of the various species of Hydnum and Hydnellum because of the extreme irregularity caused by the coarsely tuberculate types of ornamentation. In a few cases, the ornamentation and the average number of tubercles help to identify the species.

\section{Nomenclature}

Fries in 1821 included all fungi with spines in the genus Hydnum, and this decision was followed by mycologists until Quélet separated the group in 1878 but did not validate the names. Karsten in 1879 published similar genera but in 1881 used Quélet's names validating them. These two systems or modifications have since been widely used.

Recently Miller and Boyle (1943) drew attention to the fact that because S. F. Gray in 1821 had used the name Dentinum for $H$. repandum Fries this was a revision of the genus Hydnum L. ex Fries and therefore H. imbricatum L. ex Fries has to be the type of Hydnum. Donk (1956) contended that S. F. Gray's revision was not a revision of Hydnum L. ex Fries and that as Fries based the genus on Hydnum L., 1753, which can only be traced back to $H$. repandum, $H$. repandum is not available as the type of Dentinum. Whether the fact that Fries, following a Linnean concept of a genus (and greatly expanding it) typified that genus with the Linnean species is a point that I cannot settle. However, because the revision made by Gray does not violate the rules and since the genus Hydnum L. ex Fries was not typified by $H$. repandum until 1906 by Banker, it seems best to follow Miller and Boyle and Snell and use Dentinum for the fleshy white-spored group and Hydnum for the fleshy brown-spored group. It has been agreed that Hydnellum Karsten shall be the name for the fibrous brown-spored group instead of Calodon (Quél.) Karst. Miller and Boyle (1943) followed Quélet and kept the echinulate white-spored, toughfleshed species (=Phellodon Karst.) together with the tuberculate, brownspored, tough-fleshed species (=Hydnellum Karst.) under Calodon Quélet. We agree with Coker and Beers (1951) in keeping them separate, for our experience has shown Phellodon to be a natural group, distinctive and easily recognized in the field and herbarium. Its echinulate, white spores are, under the oil immersion lens, readily distinguishable from the tuberculate, brown spores of Hydnellum and Hydnum. Also the typical phellodon 
(fenugreek) odor is quite distinctive. However, the problem of whether to retain Coker and Beer's genus Bankera with white, subspiny spores as distinct from Phellodon is more difficult. The species B. fuligineo-alba and $B$. carnosa could be good phellodons according to the above method of classification, for in them it is difficult to separate subspiny from shiny spores; however, they are distinct from the phellodons by reason of 0 brittle flesh. Since this same flesh character is used to separate the genus Hydnum from Hydnellum in the tuberculate, brown-spored group, it was decided to retain Bankera as distinct from Phellodon.

The most recent study of the stipitate hydnums has been made by Dr. Maas Geesteranus who has restudied many original European collections and in particular the material in the Persoon herbarium in the Rijksherbarium, Leiden, and is now publishing a series of monographs on the stipitate hydnums of the Netherlands. His choice of genera has been the same as in this paper with the exception that he has retained Hydnum for the fleshy, white-spored group typified by $H$. repandum and Sarcodon Karst. for the brittle-fleshed, tuberculate, brown-spored group typified by H. imbricatum.

The present paper deals with the northern equivalent of the group monographed by Coker and Beers in 1951 and detailed descriptions are not given for all genera and species unless the Nova Scotian material differs. The following key was prepared for separating the genera contained in this paper.

\section{Taxonomy}

\section{Key to the Genera of Stipitate Hydnaceae in Nova Scotia}

A. Sporophores pileate and stipitate, growing on the ground.

a. Spores white, smooth.

1. Sporophores small, white to creamycolored. Like the Hydnaceae.

2. Sporophores large, fleshy.

Sistotrema confluens

Dentinum

b. Spores white, rough, (echinulate).

1. Sporophores tough, small, hairy.

Auriscalpium

2. Sporophores tough, fibrous.

Phellodon

3. Sporophores fleshy, sometimes fragile.

Bankera

c. Spores brown, rough, (tuberculate).

1. Sporophores fleshy, sometimes fragile.

Hydnum

2. Sporophores tough, fibrous.

Hydnellum

B. Sporophores growing on wood.

1. Resupinate or stipitate.

Steccherinum

2. Nodular or branched.

Hericium 
Sistotrema Fries, Syst. Myc. I: 426. 1821.

Sistotrema S. F. Gray, Nat. Arr. Brit. Plants 1: 648. 1821.

This genus is not a member of the Hydnaceae and has been considered as belonging to the Polyporaceae by Miller and Boyle (1943). It is included here because the following species has been found several times and outwardly resembles the Hydnaceae.

Sistotrema confluens Pers. ex Fries, Syst. Myc. I: 426. 1821.

Hydnum sublamellosum Bull., Hist. Champ. Fr. 306. 1791.

Sistrotrema confluens Pers., Römer's Neues Mag. Bot. 1: 108. 1794.

A number of collections of this species have been made during late September and early October on duff in spruce (Picea spp.) woods. On one occasion upwards of a hundred sporophores were found forming an arc of a fairy ring. It also occurs singly.

The peculiar development of the spines from folds and lamellae, which can be almost poroid at times, and the peculiar rancid odor are characteristic of the species in Nova Scotia. The creamy white sporophores dry to a deep creamy shade. Spores are smooth, 2.5-3 $\times 4-5.5 \mu$. This is slightly larger than the range given by Coker and Beers (1951). Basidia with 6 sterigmata have been observed.

Auriscalpium S. F. Gray, Nat. Arr. Brit. Plants 1:650. 1821.

Sporophores dark brown, tough; pileus small, hairy, usually attached laterally to a slender hairy stem.

Auriscalpium vulgare S. F. Gray, Nat. Arr. Brit. Plants 1:650. 1821.

Hydnum auriscalpium Fries, Syst. Myc. I: 406. 1821.

Auriscalpium auriscalpium (L. ex Fries) Banker, Mem. Torrey Bot. Club 12: 178. 1906.

Pileus up to $2 \mathrm{~cm}$., eccentric, densely covered with short brown hairs; spines fine, dark brown. Stipe slender, hairy, thicker downwards. Spores subglobose 4-5 $\times 5-6 \mu$. A small distinctive species that occurs on the rotting cones of pines. It was not found until late in 1959 when it was collected in Cumberland County on cones of Pinus banksiana and near Kentville in a recent planting of $P$. sylvestris.

Dentinum S. F. Gray, Nat. Arr. Brit. Plants 1: 650. 1821.

Hydnum Fries, Syst. Myc. I: 397. 1821.

Tyrodon Karst., Rev. Myc. 3: 19. 1881.

Hypothele Paulet ex Banker, Torreya 4: 113. 1904.

Miller and Boyle (1943) first presented the evidence that the name Dentinum should be used instead of Hydnum for this well-known genus. Three species and one variety have been recognized in Nova Scotia. 
Dentinum Repandum (Fries) S. F. Gray, Nat. Arr. Brit. Plants 1: 650. 1821, var. REPANDUM.

Hydnum repandum Fries, Syst. Myc. I: 400. 1821.

Tyrodon repandus (Fries) Karst., Rev. Myc. 3: 19. 1881.

Sarcodon repandus (Fries) Quél., in Cooke and Quél., Clav. Hymen. 196. 1878.

This well-known and variable species is common throughout the province and numerous collections have been made. Spores globose, $6.5-8.5 \mu$.

Dentinum REPANDUM (Fries) S. F. Gray var. album (Quél.) comb. nov.

Sarcodon repandus var. albus Quél., Flore Mycol. Fr. 447. 1888. Hydnum repandum var. album (Quél.) Rea, Brit. Basid. 630. 1922.

Three collections of this variety have been found. It is pure white and care has to be taken in its identification for the species can be almost white when it grows in semidarkness in hollow logs and stumps. The spores are the same as in the species. On being handled it develops stains that are similar to those on the species.

Dentinum Albidum (Peck) Snell, Mycologia 37: 51. 1945.

Hydnum albidum Peck, Bull. N.Y. State Mus. 1: 10. 1887.

This is outwardly like the preceding but the spores are ovoid, 4.5-6 $\times$ $3-4.5 \mu$. It has been collected only once.

Dentinum umbilicatum (Peck) Pouzar, Č Ceská Mykol. 10: 76. 1956.

Hydnum umbilicatum Peck, Bull. N.Y. State Mus. 10: 953. 1902.

This is similar in color to D. repandum but is smaller and has an umbilicate pileus. The spores are subglobose to broadly oval, 7.5-9 $\times$ $6-7.5 \mu$.

Phellodon Karst., Rev. Myc. 3: 19. 1881.

Flesh tough, fibrous; spores white, echinulate, small. All Nova Scotia species have a peculiar, pleasant odor when dry and, although varying in different species, this odor is described usually as resembling fenugreek. The similarity in smell of some of the species of hydnums to certain wellknown plants has been used by Coker and Beers (1951) to assist in their recognition. However, these similarities are not useful for Nova Scotia where hickory nuts, rabbit tobacco, and slippery elm do not occur. Four species and one variety of Phellodon have been collected in Nova Scotia and form a very distinctive group. The genus is closely related to Bankera, from which it was separated because the latter has brittle flesh and subspiny spores. A single key has been prepared for the two genera.

$93458-8-2 \frac{1}{2}$ 


\section{Key to the species of Phellodon and Bankera in Nova Scotia}

A. Pileus strongly zonate.

B. Pileus not strongly zonate.

a. Stipe thin.

b. Stipe thickened by felty layer.

i. Spines up to $4 \mathrm{~mm}$. Flesh black.

a. Surface of pileus gray, floccose often depressed.

b. Surface of pileus light gray to brown, pubescent, often convex.

ii. Spines not over $2 \mathrm{~mm}$. Flesh not black.

c. Stipe thick, fleshy.

i. Pileus large, usually convex and glabrous, under Pinus spp.

ii. Pileus smaller, usually depressed and somewhat scaly when mature, under Abies and Picea.
P. tomentosus

P. melaleucus
P. niger var. alboniger

P. confluens

Bankera fuligineo-alba

B. carnosa

Phellodon tomentosus (Fries) Banker, Mem. Torrey Bot. Club 12: 171. 1906.

(Plate 1, Figure 4)

Hydnum tomentosum Fries, Syst. Myc. I: 405. 1821.

Hydnum coriaceo-membranaceum Schw., Trans. Am. Phil. Soc. 2. 4: 162.1832

Phellodon cyathiformis Karst., Rev. Mycol. 3: 19. 1881.

Calodon cyathiformis Quél., Ench. Fung. 191. 1886.

Hydnum graveolens subzonatum Peck, Bull. N.Y. State Mus. 75: 24. 1904.

A common, variable, thin, light brown, strongly zonate species found growing in fused sheets in coniferous woods, usually under spruce or pine. Spores globose, echinulate, $3-4 \mu$. Two North American variations have been named, but since attempts to distinguish these in the present study have not been successful the synonomy of Coker and Beers (1951) is followed.

Phellodon melaleucus (Fries) Karst., Rev. Myc. 3: 19. 1881.

(Plate 1, Figure 3)

Hydnum melaleucum Fries, Syst. Myc. I: 406. 1821.

Phellodon ellisianus Banker, Mem. Torrey Bot. Club 12: 174. 1906.

Pileus 1-6 cm., single or fused, plane, depressed, white tomentose, tomentum collapsing to dark brown in the center and silky gray on the margin; surface slightly scrobiculate at center, radiating, silky; margin sterile, blunt, then thin. Flesh dark brown, thin, no odor or taste; rigid when dry and then with odor of fenugreek. Spines up to $1 \mathrm{~mm}$., grayish white to grayish brown, distant when young. Stipe up to $3.5 \times 0.3 \mathrm{~cm}$., dark brown to black, often with a slender, very brittle root (up to $10 \mathrm{~cm}$. in length) that normally breaks off. The stipe may be branched for sometimes 
there appears to be a succession of pilei from one root, the stipes remaining as stubs. Harvey (1958) recently described the proliferation of the stipes of Hydnum auriscalpium (Auriscalpium vulgare) and his account may provide a better explanation of the origin of these stubs. Spores subglobose, echinulate, $3-4.5 \mu$. Sterigmata short and fine, $2 \mu$ in length, close together on the end. Basidia $6 \mu$ in diameter.

The Nova Scotia collections were originally recognized as identical with $P$. ellisianus when compared with the type collection in the New York Botanical Garden and with Coker's collection of this species at Chapel Hill. Later, the species was found to be identical with collections of Hydnum melaleucum in the Farlow Herbarium made by von Höehnel in Austria and Karsten in Finland. Recently specimens of this species have been received from Holland through the kindness of Dr. R. A. Maas Geesteranus of the Rijksherbarium, Leiden, and found to be the same. Plate 307 in Michael and Schulz (1927) is a good illustration of this fungus as it occurs in Nova Scotia when wet and actively growing. This, under the name $P$. ellisianus, has been considered a rare species in North America but in Nova Scotia it is comparatively common and found year after year in the same spots in coniferous and mixed woods. The most luxuriant growth has been found around an old stump of balsam fir (Abies balsamea (L.) Mill.) near Kentville, where it has been collected every year since 1951. It is a small gregarious species usually with some of the pilei fused. When young and wet its white margin on a black pileus is very distinctive. It is characterized by its delicate stature, dark finely scrobiculate center, radiating silky surface, light margin, and slender brittle rooting stipe.

This paper was originally prepared with the descriptions of two species $P$. melaleucus and $P$. graveolens (Delastre in Fries) Banker, evidence for the occurrence of the latter in the province being based on two very small collections. Maas Geesteranus (1958) considered the latter a synonym of $P$. melaleucus.

Banker (1906) originally placed Hydnum melaleucum as a synonym of $P$. graveolens. This decision was followed by.Coker and Beers (1951), who, however, had some doubts, for they discussed the possibility that two species exist, one in deciduous woods and one in coniferous woods. Wehmeyer (1951) reported P. graveolens as common in Kings County, but his report was based on a herbarium list supplied from Kentville in which this name was used incorrectly for another species.

The original comments prepared for the discussion of $P$. graveolens follow. "This is a stouter plant than P. melaleucus. It is extremely rare and only two small collections have been made in mixed woods. It is a short-lived form that is inclined to collapse and dry to a black brittle mass with very little resemblance to its normal appearance. A number of collections considered to be this form have had to be discarded because of this 
condition. In Nova Scotia it is quite similar to $P$. melaleucus in appearance but is larger and not so dark in color. It has a much thinner stipe and pileus than $P$. confluens."

It seems highly probable that two species exist in North America. One is P. melaleucus of Europe, which is common in Nova Scotia and rare elsewhere, while the other, considered to be $P$. graveolens by Banker (1913), is common in the state of New York. The two overlap somewhat in size and color but are readily distinguished because the small specimens in collections of ' $P$. graveolens' of the same size as $P$. melaleucus have thicker pilei, stouter stems and lighter colored, thicker margins. Banker (1913) and Coker and Beers (1951) discuss the similarity between ' $P$. graveolens' and $P$. amicus ( $=P$. confluens) and the characters just mentioned are ones that are common to both species. Maas Geesteranus (1958) stresses the variability of $P$. melaleucus in Europe but does not mention any difficulty in separating it from $P$. confluens. This is one reason for thinking that ' $P$. graveolens' as known in America is a distinct species. Moreover if it is only an ecological variation of $P$. melaleucus then it is rather remarkable that there is not a greater response to the various habitats in Nova Scotia.

\section{Phellodon Niger (Fries) Karst., Rev. Mycol. 3: 19. 1881, var. NIGer (Plate 1, Figure 1) \\ Hydnum nigrum Fries, Syst. Myc. I: 404. 1821. \\ Hydnellum nigrum Karst., Medd. Soc. Fauna Fl. Fenn. 5: 41. 1879. Calodon niger Quél., Ench. Fung. 191. 1886.}

Pileus 5-7.5 cm., convex, plane, depressed, velvety to strigose, tomentum collapsing in age, whitish-gray to dark brownish-gray at center; margin thick, then thin, light gray. Flesh duplex, upper layer soft, same color as surface, lower layer and in stipe hard, black; no odor or taste, when dried odor of fenugreek. Spines 2.5-4 mm., light gray, darker when bruised. Stipe dark gray, base bulbous with tomentum which forms a thick, felty, water-absorbing layer. Spores globose, echinulate, 3.5-4.5 $\mu$.

Gregarious in restricted areas under red pine (Pinus resinosa Ait.) and spruce (Picea spp.). In 1959, for the first time, a very young sporophore was observed exuding droplets of black juice. Humidity was very high and the specimen was growing in a depression protected by overhanging pine straw. Neighboring sporophores at the same stage of growth but standing more in the open were dry. A detailed comparison of the typical variety with var. alboniger follows under the latter.

Phellodon Niger (Fries) Karst. var. alboniger (Peck) comb. nov.

(Plate 1, Figure 2)

Phellodon alboniger (Peck) Banker, Mem. Torrey Bot. Club 12: 167. 1906.

Hydnum albonigrum Peck, Rept. N.Y. State Mus. 50: 110. 1897.

Calodon alboniger (Peck) Seeler, Rhodora 44: 168. 1942. 
Pileus 3-9 cm., occasionally fused, convex, sometimes plane or depressed, when very young grayish-white and center gray, finally dark with center dull brown; surface tomentose to smooth at center; margin at first thick, blue-gray, later thin, lighter, taking a finger print, darkening when bruised. Flesh duplex, soft, upper layer dull brown or concolorous with surface, lower layer and in stem, firm and black. Slight odor, strong when drying, taste none-recorded as slightly biting in one collection. Spines 2.5-4 mm., light gray, slightly decurrent, often with a circular pattern in the fall. Stipe $4-10 \times 1-2 \mathrm{~cm}$., light brown, then dark brown, bulbous felted, base up to $3 \mathrm{~cm}$. in diameter from the water-absorbing layer of mycelium. Spores globose to subglobose, echinulate, 4-5u.

Gregarious in coniferous woods. The felty layer of mycelium that is around the stipe of $P$. niger and var. alboniger develops most luxuriantly in deep moss or thick pine straw. The pileus originates from the apex of this column. On bare ground or where there is only a thin layer of duff present the sporophores are much smaller and the felty mycelium is reduced to a small pad at the base of a short, slender stipe. Bresadola's (1932) Plate 1055 of $P$. alboniger is typical of one stage of growth as it occurs in Nova Scotia.

The new variety has the same general appearance as var. niger except that the younger sporophores are a lighter shade and the mature sporophores are dark brownish instead of dark grayish. The sporophores tend to be larger; the surface is more strigose, irregular, and not so depressed; the spines are stouter and the spores are slightly larger in most collections. In some seasons the two are easily separated because the young sporophores of var. alboniger are light gray and the older pilei dull brown. In other years the two are quite similar and can be easily separated only when freshly collected. It is rarely possible to identify the dried specimens of overmature sporophores. The variety alboniger has been more widely collected in Nova Scotia than the typical variety. The two have been compared frequently when growing side by side. $P$. alboniger was considered by Lloyd (1922, Note 1128) to be the same as P. niger of Europe whereas other mycologists have considered it distinct because of its odor in contrast to the reported lack of odor of the European form. Coker and Beers' (1951) description of $P$. alboniger includes both varieties. Most of the collections in the Chapel Hill herbarium are var. alboniger and only a few are var. niger. Banker (1906) considered that there were two species in North America.

Phellodon confluens (Pers.) Pouz. Česká Mykol. 10: 74. 1956.

Hydnum confluens Pers., Mycol. Europ. 2: 165. 1825.

Hydnum amicum Quél., Grevillea 8: 115. 1880.

Calodon amicus Quél., Assoc. Franç. Avance. Sci. 12: 504. 1884.

Hydnum vellereum Peck. Rept. N.Y. State Mus. 50: 110. 1897.

Phellodon amicus (Quél.) Banker, Mycologia 5: 62. 1913. 
A medium-sized species with sporophores up to $6 \mathrm{~cm}$., often fused, plane or depressed, very irregular and lobed, surface tomentose, whitish to creamy-buff and becoming browner toward center, flesh soft, concolorous, harder and darker downward. Spines up to $2 \mathrm{~mm}$., whitish-buff, later gray-brown. Stem short, excentric, concolorous. Spores globose, echinulate, $3-4 \mu$.

Gregarious in deciduous or mixed woods. Only one small sporophore of this species has been collected by the author in Nova Scotia. Wehmeyer (1951) reports $P$. vellereus (Peck) Banker, from Colchester County, which is a synonym according to Coker and Beers (1951).

BANkera Coker \& Beers ex Pouzar, Česká Mykol. 9: 95. 1955.

Bankera. Coker \& Beers, Stip. hyd. east. U.S. 33. 1951.

This genus was erected by Coker and Beers for $H$. fuligineo-album Schmidt ex Fries, which is distinguished by its brittle flesh and white subspiny spores. The genus bears the same relationship to Phellodon in the echinulate white-spored group that Hydnum does to Hydnellum in the tuberculate brown-spored group.

Bankera fuligineo-Alba (Schmidt ex Fries) Pouz. Česká Mykol. 9: 96. 1955.

(Plate 1, Figure 5)

Hydnum fuligineo-album Schmidt, in Kunze and Schmidt, Mykol. Hefte 1: 88. 1817.

Hydnum fuligineo-album Fries, Syst. Myc. I: 400. 1821.

Pileus 8-15 cm., convex, plane, umbonate, depressed or umbilicate, straw-colored, dark brown when moist, with lighter margin; surface bibulous, relatively smooth, soft, sometimes with encrusted duff; margin blunt, incurved, sterile when young, spines to the edge in age. Flesh soft and brittle, light brown; no taste, odor of fenugreek, when drying, that persists in herbarium material. Spines to $6 \mathrm{~mm}$., rather stout, whitish with lighter tips. Stipe $3-4 \times 1.6-2 \mathrm{~cm}$., smooth, concolorous, sometimes fused. Spores subglobose, echinulate, 3.5-5 $\times 3.5-4 \mu$.

Solitary or rarely gregarious under mats of red pine needles in the Annapolis Valley. This is a short, stout, fleshy species that usually remains covered by the pine straw and is found only with great difficulty. The rosy color described by others and illustrated by Bresadola (1932, Plate 1047 ) is apparent in only a few of the young specimens of this species. The surface is usually smooth but absorbs water very quickly and when saturated in dark brown. It has been collected in two blocks of red pine (Pinus resinosa Ait.). Coker and Beers (1951) and Maas Geesteranus (1958) in the synonymy of this species include Hydnum fragile Fries, which has been done here. Fries described $H$. fragile in 1851 and the original description could apply to $B$. fuligineo-alba as understood in 
Nova Scotia. Another species present in the province is grayish-brown and is considered to be the same as Phellodon carnosus Banker, although under the favorable conditions in Nova Scotia it grows much larger than indicated in the original description. It has been difficult to place this species but now it has been decided to keep the American form under the name given by Banker. The typical form of $B$. carnosa has been found in the red-pine habitat but only near spruce and this further supports our belief that they are separate species.

BANKera CARnosa (Banker) Snell, Dick \& Taussig, in Snell et al., Lloydia 19: 174.1956.

(Plate 1, Figure 6)

Phellodon carnosus Banker, Mycologia 5: 65. 1913.

Hydnum carnosum (Banker) Trotter, Syll. Fung. 23: 472. 1925.

Pileus 3-10 cm., light grayish-brown, convex, plane to depressed; surface smooth, then cracked and scaly; margin split, incurved and sterile. Flesh fragile, particularly in age, brown, scissile; odor mild fenugreek, stronger as it dries. Stipe, $2-7 \times 0.5-2.0 \mathrm{~cm}$., tapering downwards, concolorous, surface smooth or lacerate, base blackening occasionally, flesh scissile and with a harder core. Spines up to $4 \mathrm{~mm}$., fine, decurrent, pale gray, finally concolorous, easily broken off leaving a reticulated pattern. Spores globose, echinulate, white, 3.5-5 $\mu$.

Solitary, gregarious or caespitose and often irregular from crowding, in coniferous or mixed woods. This is a common species in Nova Scotia and has been found in many localities and in many different stages of development. It has been found from July to October for five seasons on one particular hummock at Aylesford Lake, and has been consistent in its manner of growth and habit.

This species has not been found in pure stands of pine and originally was identified as $H$. fragile Fr. from the descriptions given by Rea (1922, p. 631). However, recently several collections have been made of obviously dwarfed young plants which were similar in outline and appearance to those illustrated as Phellodon carnosus Banker in Coker and Beers (1951, Plate 19). Examination of the type in the New York Botanical Garden and Coker's collection at Chapel Hill showed that $P$. carnosus Banker is based on young, somewhat depauperate material identical with the collections made in Nova Scotia. Snell et al. (1956) discuss B. carnosa and its relationships in detail.

Hydnum (Fries) S. F. Gray, Nat. Arr. Brit. Plants 1: 650. 1821.

Sarcodon Karst., Rev. Mycol. 3: 20. 1881.

Sporophores stipitate, flesh brittle, with coarsely tuberculate brown spores; usually large and variable. It is difficult to draw a sharp line between the two genera, Hydnum and Hydnellum, under all conditions of growth. 


\section{Key to the Genus Hydnum in Nova Scotia}

A. Flesh bitter, apparent very slowly in some species.

a. Pileus coarsely scaly when mature.

i. Flesh blackening in $\mathrm{KOH}$, very scabrosum bitter.

ii. Flesh not blackening in $\mathrm{KOH}$, very fennicum bitter.

iii. Flesh not blackening in KOH, imbricatum slightly bitter.

b. Pileus slightly scaly.

i. Brown, flesh turning blue-green in amarescens $\mathrm{KOH}$.

ii. Brown, flesh not changing in $\mathrm{KOH}$, subfelleum very slowly bitter.

iii. Yellowish, flesh mild or only slightly crassum bitter.

B. Flesh farinaceous.

a. Surface scaly, spines incarnate, later lanuginosum gray.

b. Surface smooth or slightly scaly, spines stereosarcinon brown.

c. Surface smooth or obscurely scaly, spines undescribed, first seen by orange-brown, later dark brown.

Dr. Snell in Que.

C. Flesh acrid, pileus strigose.

a. Stipe 2.5-6.5 $\mathrm{cm}$. Pileus yellowish to cristatum buff-brown.

b. Stipe short, exudes watery juice when Hydnellum mirabile broken. Pileus khaki to dark brown.

Hydnum SCABRosum Fries, Anteckn. öfv. i Sverige väx. ätl. Svamp. 62. 1836.

(Plate 1, Figures 7 and 8 )

Sarcodon scabrosus (Fries) Karst. Rev. Mycol. 3: 20. 1881.

Sporophores up to $20 \mathrm{~cm}$. in diameter, single or gregarious. Pileus convex to infundibuliform, glabrous when covered by duff, becoming finely or coarsely scaly, isabelline when young, later chestnut with vinaceous tints, becoming dull brown with darker scales, margin incurved. Flesh soft, brittle, isabelline, darker in age. Taste very bitter, odor slight. Spines up to $5 \mathrm{~mm}$., fine, concolorous or paler. Stipe short or long, pointed or blunt in age, dull black at the base and white mycelioid. Spores sub-

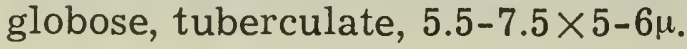


A test with $\mathrm{KOH}$ that will turn the flesh of $H$. scabrosum blue-green is used in Europe to separate it from $H$. fennicum, which does not so react. This will have to be used with caution here for only a small part of the flesh of the Nova Scotia specimens tested resulted in a blue-green shade. The surface tissue blackened immediately. We have not had an authentic specimen of $H$. fennicum to test for a comparison.

Usually found in coniferous, occasionally in mixed, woods, this is a variable and comparatively common species in Nova Scotia. It undergoes remarkable changes as it grows. The earliest stages seen were found under the pine straw of Pinus resinosa and had the general outline of D. repandum but differed in being isabelline, and in the short fine spines. The sporophores gradually change color, become scaly, and expand to plane or infundibuliform, with the occasional specimen perforate into the stipe. The base of the stipe develops its characteristic blackish color slowly. The largest specimen found was under red pine, weighed $246 \mathrm{gm}$. and was $20 \mathrm{~cm}$. in diameter. This species was originally identified as Hydnum fennicum (Karst.) Sacc. but collections sent to Dr. Maas Geesteranus were considered identical with $H$. scabrosum.

Some of the variations of this species collected in Nova Scotia have resembled Sarcodon underwoodii Banker and $S$. murrillii Banker but were not quite typical of these southern forms. Because of this and the ecological variability so apparent in Nova Scotia it is hoped that someone will find an opportunity to study these southern species under varying conditions.

H. scabrosum also has been confused in North America with $H$. imbricatum Fries from which it may be distinguished by the intensely bitter taste and the blackish base of the stipe.

Hydnum FenNicum (Karst.) Sacc., Syll. Fung. 6: 433. 1888.

Sarcodon scabrosus var. fennicus Karst. Bidr. känned Finl. Nat. Folk 37: 104. 1882.

Sarcodon fennicus (Karst.) Karst., Rev. Mycol. 9: 10. 1887.

It is highly probable that this species occurs in Nova Scotia and that it will be found, now that comparative details are known. Maas Geesteranus (1956) states that this is a "fairly pale species. Pileus yellowbrown or with a rufous tinge (more rarely somewhat vinaceous), trama white or tinged with bistre in stipe, not discoloring with $\mathrm{KOH}$, stem usually slender." He accepts Coker and Beers' account of its occurrence in North Carolina, but many of the collections at Chapel Hill, seen by me, were the same as the common species in Nova Scotia. They were not tested with $\mathrm{KOH}$. It is certain that $H$. fennicum and $H$. scabrosum as they occur in North America require further study. 
Hydnum IMbricatum Fries, Syst. Myc. I: 398. 1821.

(Plate 1, Figure 9)

Sarcodon imbricatus (L. ex Fries) Karst., Rev. Mycol. 3: 20.1881.

This is a large dark brown plant of regular outline and bears a resemblance to $H$. scabrosum. However, it is only slightly bitter and has regular prominent scales even when quite young. A specimen $25 \mathrm{~cm}$. in diameter has been found. Spores 6-8 $\times 5-7 \mu$, brown, subglobose, tuberculate. It is a well-known species that is common locally along the Bay of Fundy shore but is rare in other parts of Nova Scotia. It grows under fir and spruce. Collected once at Kentville, once near Steam Mill Village and in quantities every year since 1951 in one small area on Cape Split. In 1958 a partial fairy ring was found, some 40 feet in length, which contained 80 large sporophores.

Hydnum amarescens Quél., Bull. Soc. Amis Sci. nat. Rouen 15: 172. (1879) 1880.

Sarcodon radicatus Banker, Mycologia 5: 13. 1913.

Sarcodon roseolus Banker, Mycologia 5: 16. 1913.

Hydnum roseolum (Banker) Snell, Mycologia 37: 51. 1945.

This species has not been collected by the author, but Wehmeyer (1951) reports one collection from Colchester County as $S$. radicatus Banker, which Coker and Beers (1951) consider a synonym. It has been discussed by Snell (1945). The following new species resembles it in general appearance, but is distinct in a number of important details.

HYDNUM subfelleum sp. nov.

(Plate 2, Figure 2)

Pileus 4-17 cm., irregularissimus, lobatus, convexus, vinaceus, griseo-brunneus vel caeco-brunneus, glaber, subpruinosus deinde rimosus; margine incurvato, interdum elevato et in aetate attenuato; carne aurea, firma, fragili; odor tenuiter medicamentosus; gustu farinaceus, gradatim acer in fauce; aculeis ad $7 \mathrm{~mm}$., decurrentes, glaucae, pallide griseo-brunneae, saturantes si vulneratae, facile exfoliatae, cicatricibus reticulatis; stipes 1-9 $\times 1-4 \mathrm{~cm}$., concolor, crassus, irregularis, ad basas obtusus, albus atque mycelioideus; sporae alutaceae, suglobosae, grosse tuberculatae, 5-6 $\times$ 4-5 $\mu$. Gregarius vel connatus, sub Picea et Abiete apud Glenmont; rarus sed omnino in Nova Scotia.

Pileus 4-17 cm., convex, very irregular, lobed, brown with vinaceous tint when young, darkening slightly with maturity, sometimes with dark spots in age, surface smooth, finely scaly or cracked; margin incurved, undulating, thick, elevated and thin with age. Flesh isabelline, firm, brittle; odor slightly medicinal, taste farinaceous, very slowly bitter in the throat. Spines up to $7 \mathrm{~mm}$., uneven in length, light grayish-brown, glaucous, tips white, darkening when bruised, decurrent, easily rubbed off leaving a reticulated appearance to the flesh. Stipe 1-9 $\times 1-4 \mathrm{~cm}$., stout, concolorous, 
uneven, often appearing swollen, base blunt and irregular, white mycelioid, often hollowed by maggots. Spores alutaceous irregularly subglobose to angular, coarsely tuberculate, 5-6 $\times 4-5.5 \mu$.

Gregarious or caespitose under spruce and fir. Collection KM 3231 Glenmont, Kings County (DAOM 53380 TYPE). Usually found in the same areas as $H$. stereosarcinon and easily confused with it. This species is distinguished from $H$. stereosarcinon by the darker color when young, the brittle flesh, the stout uneven stipe which is fleshy instead of fibrous, the larger spores, the odor, and the taste which is slowly bitter. This species also shrinks more on drying and the surface blackens in $\mathrm{KOH}$. It has a close resemblance to $H$. amarescens as illustrated in Coker and Beers (1951, Plate 22), but the flesh does not turn blue-green in $\mathrm{KOH}$, and is not acrid. Otherwise the descriptions are very similar.

\section{HYDNUM crassum sp. nov.}

(Plate 2, Figure 3)

Pileus 5-15 cm., convexus, planus, depressus, in primis luteolus, deinde surde luteo-brunneus, tomentulosus, rimosus, margine tenui, incurvato; carne alba, aurescente; odor tenuiter medicamentosus; gustu saepius tenuiter acer; stipes 1-3 cm., concolor, attenuatus ad basas, in apice scaber; aculeis ad $1.5 \mathrm{~cm}$. long, crassis, inprimis aureis, lente brunescentibus, subalbidis in apice; sporae alutaceae, oblongae, grosse tuberculatae, $3-5 \times 2.5-4 \mu$. Rarus, solitarius vel gregarius, sub Picea apud Cape Split, prope Pinos et Tsugas apud Kentville Neoscoticorum.

Pileus 5-15 cm., convex, semiglobose, plane or depressed, yellowish, later dull yellow-brown; surface slightly tomentose, finely or rarely coarsely cracked; margin thin, incurved, rarely ascending. Flesh thick, scissile, white, later isabelline, soft, firmer in the stipe. Odor mildly medicinal, taste mild or slightly acrid in some collections. Stipe up to $3 \mathrm{~cm}$. thick, concolorous, tapering downward, base white mycelioid, apex scabrous from rudimentary yellowish spines. Spines up to $1.5 \mathrm{~cm}$., coarse, shorter toward the margin, isabelline, light brown, later dull brown with white tips arising from a compact yellowish layer in the flesh and sometimes divided into two to four tips. Spores alutaceous, oblong, coarsely tuberculate, $3-5 \times 2.5-4 \mu$. Rare, solitary, gregarious, occasionally caespitose, under spruce at Cape Split and near hemlock at Kentville. Collection KM 3548 Cape Split, Kings County (DAOM 53378 TYPE).

This species is like $H$. subfelleum in its habit of growth but has the color of $D$. repandum when young and resembles Polyporus confluens when fully developed. It might be confused with Dr. Snell's undescribed tawny species mentioned in the key. However, it differs in having thick white flesh and long coarse brown spines and in lacking the strong farinaceous taste. It is a stout, striking species that is characteristically different throughout its entire development. 
HYDNUM stereosarcinon (Wehmeyer) comb nov.

(Plate 2, Figure 1)

Sarcodon brevipes Coker, J. Elisha Mitchell Sci. Soc. 55: 375. 1939.

Sarcodon stereosarcinon Wehmeyer, Can. J. Research, C 18: 102. 1940.

Hydnum brevipes (Coker) Snell, Mycologia 37: 88. 1945; non H. brevipes Opiz, Lotos, p. 42. 1855.

Pileus 2-14 (18) cm., single or fused, very irregular, convex, plane, rarely infundibuliform, light brown darkening to dull brown, faintly zonate, occasionally in humid weather exuding light yellow juice. Surface smooth or finely scaly, sometimes cracked in dry weather; margin very irregular, undulating, drooping, thin, incurved, sterile, brownish on bruising. Flesh firm, fibrous, scissile, brownish white; taste slight, farinaceous, no odor. Spines up to $1 \mathrm{~cm}$., decurrent, fine to very coarse, subulate, or spathulate near the stem, conclorous, tips lighter and concolorous with the growing margin. Stipe 4-8 × 1-2 cm., irregular, tapering to a point, concolorous, flesh firm and fibrous, light brown, sometimes grayish (lilac in Coker and Beers, 1951) toward base of stipe; base of young plants occasionally showing droplets of reddish-brown juice. Spores subglobose to oblong, tuberculate, $4.5-5.0 \times 3.5-4.5 \mu$.

Common, solitary, gregarious or connate, under spruce and fir, particularly abundant along the Bay of Fundy shore and on Cape Breton Island. It has characteristics of both Hydnellum and Hydnum and is usually a squat, light brown plant of very irregular outline. It dries hard and woody and can easily be confused with $H$. subfelleum. Numerous variations have been collected over the years. A number of these are so distinct that if they were found in different regions they could easily be considered as varieties. However, when found in one general area they illustrate the complexity of the responses of the stipitate hydnums to various environmental factors. The more striking variations collected included depauperate forms with pilei less than $3 \mathrm{~cm}$. in diameter, small thin expanded forms, an almost white form, and others that were very deep brown. Some collections had fine close spines, while in others the spines were coarse with spathulate tips. In the late fall of 1955 , several were found with the margins almost poroid. However, they all had the typical small coarsely tuberculate spores, brownish-white flesh and farinaceous taste of $H$. stereosarcinon.

\section{HydNUM lanuginosum sp. nov.}

(Plate 1, Figure 10)

Pileus 3-15 cm., irregularissimus, convex vel depressus, roseus, cinerescens, in primis subglabrus, deinde scalis colore intento fibrillosis; margine attenuata, incurvata; carne scissili, fragili, concolore; gustu et odore farinacea; aculeis ad $6 \mathrm{~mm}$., paullum decurrentibus, concoloribus 
in primis, brunescentibus, deinde griseo-brunneis; stipes $3-6 \times 0.5-2.5$ $\mathrm{cm}$., glaber, pallide griseus, deinde brunneo-griseus; sporae alutaceae, subglobosae, tuberculatae, 4.5-6 $\times 4.5-5 \mu$.

Solitarius vel gregarius et connatus, sub Picea et Abiete apud Cape Split, in Hants, Annapolis et Antigonish comitatibus.

Pileus 3-15 cm., very irregular, convex, depressed, light gray, cinereous, incarnate when young, subglabrous when very young, soon becoming woolly, with floccose scales that darken when dry; margin thin, incurved, darker because of scales. Flesh up to $1 \mathrm{~cm}$. thick, scissile, brittle, concolorous; taste strongly farinaceous, odor similar, slight. Spines up to $6 \mathrm{~mm}$., slightly decurrent, concolorous when young, then light brown with whitish tips, finally grayish-brown. Stipes 3-6 $\times 0.5-2.5 \mathrm{~cm}$., glabrous, light gray, finally brownish-gray. Spores subglobose, tuberculate, $4.5-6 \times 4.5-5 \mu$.

Solitary or gregarious, often connate, under spruce and fir throughout Nova Scotia. Collection KM 3560 Cape Split, Kings County (DAOM 53375 TYPE). A very distinct, shaggy-appearing fungus that is characterized by the grayish smooth stem, the dark scales and the brittle flesh with a strong farinaceous taste. The scales lose some of their dark color during rains. One young collection made in 1955 showed reddish colored droplets on the base of the stem and another in 1959 showed pinkish drops on the stem.

Hydnum CRIstatum Bres., in Atkinson, Jour. Mycol. 8: 119. 1902.

Sarcodon cristatus (Bres.) Banker, Mem. Torrey Bot. Club 12: 140. 1906.

This is a species that possibly will be found in Nova Scotia. It has been reported from New York State. It is very similar to $H$. mirabile, but is more fleshy, not as firm, and with a creamy-white plush surface that becomes yellowish and strigose hairy in age instead of having the brown strigose hairy surface of the latter. The distinctive differences persist in properly dried herbarium material. Snell (1954) recently discussed the two species in detail.

Hydnellum Karst., Medd. Soc. Fauna Fl. Fenn. 5: 41. 1879.

Calodon (Quél) Karst., Rev. Mycol. 3:20. 1881.

Sporophores terrestrial, stout or thin, often connate, solitary, regular or deformed. Flesh tough and fibrous, or almost woody. Spores brown, tuberculate. Members of this genus vary in their flesh texture from hard persistent forms such as $H$. scrobiculatum and $H$. velutinum var. spongiosipes to $H$. mirabile whose flesh approaches the brittleness of Hydnum stereosarcinon. Many of the species in this genus grow slowly and in some years the seasonal weather pattern causes puzzling variations in the appearance of the sporophores so that older collections are often very difficult to identify. 


\section{Key to the genus Hydnellum In Nova Scotia}

A. Pileus whitish when young (see B and D) with tints of blue on spines or stipe.

a. Sporophores large, fragrant, base of stipe dark-violet.

b. Sporophores large, not fragrant, stipe straw-colored. Young spines tinted blue.

c. Sporophores small, gregarious, stipe whitish, spines grayish-blue.

d. Sporophores fused, fragrant, exuding red juice. Stipe rooting, spines blue.

B. Pileus or stem orange, or dull red.

a. Pileus and stipe white, becoming orange, spines and flesh dull orange.

b. Pileus and stipe similar, becoming brown. Flesh with gray or mauve tints when dried.

C. Pileus when young, and tips of spines, sulphur-yellow

D. Pileus when mature some shade of brown.

a. Flesh acrid, pileus whitish when very young, sometimes with drops of reddish juice. Stipe often rooting.

i. Flesh thick, odor fragrant.

ii. Flesh thin, or thick, not fragrant.

b. Flesh slightly acrid, pileus khaki to brown, stipe exuding sticky, watery juice.

c. Flesh not acrid.

i. Sporophores stout, usually fused, surface deeply pitted and rough, when expanded zonate.

ii. Sporophores thin, often concrescent, and zonate.

iii. Sporophores stout, depressed to infundibuliform, dull yellow-brown to fulvous, remaining dry on handling.

iv. Sporophores stout, usually convex, reddish-brown with pale tomentose margin when actively growing, staining dull red.

v. Sporophores a mass of fused stipes and overlapping pilei, dull graybrown. Spines gray then dull brown.

vi. Sporophores a complicated mass of stipes and of small overlapping pilei, brown with white margins. Spines white then brown. suaveolens

caeruleum

subzonatum

cruentum

aurantiacum

ferrugipes

geogenium

diabolus

peckii

mirabile

scrobiculatum var. scrobiculatum

scrobiculatum var. zonatum

velutinum var. velutinum

velutinum var. spongiosipes

frondosum

multiceps 
Hydnellum suaveolens (Scop. ex Fries) Karst., Medd. Soc. Fauna Fl. Fenn. 5: 41. 1879.

(Plate 2, Figure 6)

Hydnum suaveolens Scopoli, Fl. Carn. 2: 472. 1772.

Hydnum suaveolens Fries, Syst. Myc. I. 402. 1821.

Hydnum boreale Banker, in White, Bull. Torrey Bot. Club 29: 553. 1902.

Hydnellum rickerii Banker, Mycologia 5: 201. 1913.

Pileus 5-15 cm., convex, plane; surface uneven or lumpy, soft, woolly, pure white, then isabelline, finally grayish-brown; margin thick, uneven. Flesh to $2 \mathrm{~cm}$., whitish with numerous faint mauve bands, strongly fragrant (anise?). Spines up to $8 \mathrm{~mm}$., white becoming dark-brown with light gray tips, darker near the stipe. Stipe 1-4 $\times 1.5-2 \mathrm{~cm}$., white, shading to a deep violet base, mycelium lilac; flesh at base of stipe bluish-black, zoned, fading upward to light violet at the pileus. Spores very irregular and coarsely tuberculate, $3-3.5 \times 3.5-5 \mu$; sterigmata up to $2 \mu$, very fine.

Single or gregarious in spruce or mixed coniferous woods. This is a common species characterized by its squat manner of growth and white color. The youngest stage seen was a small column of fragrant, lilac mycelium with the apex turning white. It expands to a large white pileus and persists as such for a long time. The disc slowly becomes isabelline and finally darkens to gray-brown. The sporophores are strongly fragrant and have been located in the woods by their odor. The odor persists in the dried plants and is useful for the identification of off-type and badly weathered specimens.

Hydnellum Caeruleum (Hornem. ex Pers.) Karst., Medd. Soc. Fauna FI. Fenn. 5: 41. 1879.

(Plate 2, Figure 5)

Hydnum caeruleum Hornemann, Flora Danica VIII, fasc. 23: pl. 1374. 1808.

Hydnum suaveolens Scop. var. caeruleum Fries, Syst. Myc. I: 402. 1821.

Hydnum caeruleum Pers., Myc., Europ. 162. 1825.

Hydnum cyaneotinctum Peck, Bull. Torrey Bot. Club 30: 98. 1903.

Hydnellum cyaneotinctum (Peck) Banker, Mem. Torrey Bot. Club 12: 164.1906.

Pileus 3-11 cm., convex, plane, sometimes depressed, mauve then whitish, becoming light brown at center, finally dull dark brown; margin white and lightly tinted with blue when growing rapidly, later isabelline shading into brown at the center; surface soft, velvety, darker when bruised, finally matted and pitted from collapsed tomentum. Flesh thick, upper layer soft, lower layer compact, light buff, zonate with bands of mauve and brown, shading to reddish-brown in the lower part of stipe, no taste and slight odor. Spines 3-5 mm., deeply decurrent, close, whitish when young with an overcast of mauve, becoming dark-brown with 
white tips. Stipe 2-4 $\times 1-2 \mathrm{~cm}$., tapering downward into a bulbous, strawcolored base, finally dark brown especially after the straw-colored felty surface has been eaten by slugs. Spores irregular, subglobose to oblong, tuberculate, $4.5-6 \times 4.5-5.5 \mu$. On one occasion drops of pale yellow juice were observed on the pilei of young actively growing sporophores.

Gregarious, occasionally fused, under red pine in the Annapolis Valley and in coniferous woods throughout Nova Scotia. Rare but common locally. It starts as a tiny tomentose column of straw-colored mycelium. As it enlarges a bluish spot appears on the apex that elongates and expands to become the pileus.

This is a very squat compact species that only shows bluish shades when actively growing. The color is more intense in cool autumn weather. It is recognized by the thick, light-colored, blue-zoned flesh of the pileus, and the reddish brick-colored flesh in the stipe. Old specimens are quite brown, others are brown at center shading to a light margin. Wehmeyer (1940) reports finding this species in Colchester County but mentions the presence of red juice, a rooting stipe and a fragrant odor, none of which are present in $H$. caeruleum but are characteristic of $H$. cruentum sp. nov., described in this paper. There is a collection of $H$. cyaneotinctum in the New York Botanical Garden made by Peck at Horicon, Warren County, New York, July 22, 1905, and sent to Banker (specimen ex herbarium Howard J. Banker 1065). Peck's type for this species has not been found and as this collection was considered typical by him it is designated as the lectotype. Donk (1933) first pointed out that $H$. cyaneotinctum Peck was synonymous with $H$. caeruleum of Europe. Coker's collections from North Carolina at Chapel Hill are not the same as the species discussed here but are $H$. ferrugipes Coker and show a much higher proportion of blue in the flesh than is usual in the type material. Several of the collections were originally marked as $H$. ferrugipes by Coker and later changed. Bresadola's (1932) Plate 1051 of $H$. caeruleum and the original Plate 1374 by Hornemann in the Flora Danica are excellent illustrations of this species as it occurs in Nova Scotia. A giant variation with one pileus $26 \mathrm{~cm}$. in diameter, and stipes up to 15 $\mathrm{cm}$. long, has been collected a number of times at North Williamston, Annapolis County. This form differs in some details but for the present is considered a luxuriant form growing under exceptionally favorable conditions.

Hydnellum aURantracum (Batsch ex Fries) Karst., Medd. Soc. Fauna

Fl. Fenn. 5: 41.1879.

(Plate 3, Figure 6)

Hydnum aurantiacum Alb. \& Schw., Consp. Fung. 265. 1805. Hydnum floriforme Schaeff. in part, Fung. Bav. 4: 97. 1774. 
Pileus 5-15 cm. turbinate, expanding, plane, depressed, white, turns bright orange and finally dark brown at center; margin blunt and white, then thin; surface velvety taking a finger print, lumpy ('bubbly') with rounded processes, finally dark, uneven. Flesh duplex, thick and solid, later thin, dull brown, occasionally tints of gray or mauve when dry, no odor or taste. Spines $3-4 \mathrm{~mm}$., white, turning brown with light tips, finally dark brown, darkest near the stipe. Stipe 3-4 $\times 1-1.5 \mathrm{~cm}$., orange, turning bright rusty, finally dark brown, surface felted, flesh of stipe orange-brown, darker downward. Spores subglobose, rough tuberculate, $5.5-7.5 \times 5-6 \mu$.

Gregarious or concrescent in coniferous woods. Most common on the edge of hummocks on the sandy plain at North Williamston, in mixtures of pine and spruce. This has been collected many times and is a very striking, variable species. It is hard to believe that it changes so completely, but several times all stages have been found growing together. This species is not so long-lived as the variation described later and is much more common. H. aurantiacum appears early in the summer and young sporophores may be found any time from early July to early September. It has large, distinctive spores.

The above is only a partial solution of the problem of the classification of the orange-colored hydnums in Nova Scotia. The following description is included as an example of the variability that exists in this confusing complex of forms. It is possible that it (Plate 3, Figure 5) should be considered a species but for the present it is left as a rather clear-cut variation.

Pileus 2-10 cm., turbinate, concrescent, convex, plane, depressed, scrobiculate, whitish, orange, light gold-brown (dull when water-soaked); margin blunt, elevated, wavy, whitish with orange tints; surface rough, with thin soft velvety layer, firm beneath. Flesh fibrous, solid, orange near surface, light orange-brown with bands of dark brown, orangebrown downward in stipe. Stipes 3-4 $\times 1 \mathrm{~cm}$., single or connate, irregular, tapering downward, orange-brown to rusty-brown, lighter colored and tomentose at base. The stipe has a hard lighter colored inner core. Spores irregular, subglobose, roughly tuberculate, 4.5-6 $\times 3.5-4.5 \mu$.

Solitary or gregarious under red pine. The plant is white tomentose when young but soon becomes dull orange and later takes on an undertone of brown. The persistent orange shade of the spines greatly assists in the recognition of this form. It also has very solid compact sporophores with a scrobiculate surface that blends so effectively into the background of red pine needles that, unless the specimens are large, they are extremely difficult to see. When young, the sporophores cannot be distinguished from $H$. aurantiacum, but the later stages are distinctly rough 
and do not expand to a thin pileus. The flesh is dull orange, zonate with dark bands and never shows bluish-gray tints.

The form has been collected in the Annapolis Valley and its development has been followed during the late summer and fall for four seasons. A collection under the name $H$. aurantiacum made by Romell in Sweden and now in the Chapel Hill herbarium is identical with this Nova Scotia form.

Coker and Beers (1951, Plate 41) is quite similar in outline and surface appearance to $H$. aurantiacum but the collections in the Chapel Hill herbarium have soft reddish-orange flesh and according to Coker and Beers are identical with $H$. earlianum Banker. This latter species is easily identified in herbarium specimens because it has light zonate softtextured flesh, 'friable' according to Coker and Beers, while $H$. aurantiacum is solid, fused, with zonate tougher scissile flesh. $H$. earlianum Banker, is a synonym of Hydnellum complicatum Banker. The two have distinctive friable flesh and the microscopic details of the mycelium and spores as illustrated in Plates 59 and 60 of Coker and Beers (1951) are in agreement. It has not been collected in Nova Scotia but is known from Ontario.

In his publication on the genus Hydnellum, Maas Geesteranus (1957) states that two collections from Nova Scotia sent as $H$. ferrugipes are identical with $H$. aurantiacum of Europe. He considers $H$. ferrugipes as distinct because of its blue flesh. The blue color in this study has been considered a somewhat variable character and slight traces of blue have been noticed in some Nova Scotia specimens, but now all large-spored hydnums that agreed otherwise have been classified as $H$. aurantiacum while the more orange, smaller-spored forms found under Pinus resinosa, have been considered as a variation. However, three other collections are so distinct that more material is needed before it will be possible to reach a decision as to their status. One collection was typical of $H$. conigenum (Peck) Banker except that it was not growing on cones. This is considered a doubtful character as all Hydnellums will surround various small objects encountered in their growth and the type indicates that this was probably the case in $H$. conigenum. Also, collections of what appear to be this form from British Columbia, sent by Dr. W. G. Ziller, were not usually attached to cones. Another collection was very much larger, thicker, rougher and of a darker color. It was found growing at North Williamston in the same block of pine as $H$. aurantiacum and its variation. A third collection found in Cape Breton was almost white; very little orange color was present and the older parts in the center were dull brown. These all may be extremes of this one complex species but until collections are made connecting them it seems better to keep them separate. 


\section{HYDNELLUM subzonatum sp. nov.}

\section{(Plate 3, Figure 2)}

Pileus 1.3-5 cm., depressus, concrescens, in primis albidus, deinde pallide brunneus, subzonatus, secundum radios costatus; saturatus ad centrum, paullum scrobiculatus; margine crasso, tenuescente, albo, elevato, nonnunquam sterili per $2 \mathrm{~mm}$; carne $2-3 \mathrm{~mm}$., tenui, pallide brunnea; odor fungi; gustu farinaceus; stipes 1-5 $\times 0.15-0.3 \mathrm{~cm}$., concolor, subzonatus, connatus, gradatim dilatatus; aculeae ad $3 \mathrm{~mm}$., paullulum decurrentes, tenues, denses, caesiae sed acuminibus albis, deinde griseo-brunneis; sporae alutaceae, oblongae, tuberculatae, tuberculis acutis, 3.5-4.5 $\times 3-4 \mu$. Rarus, gregarius, connatus, sub Picea apud Cape Split et apud Aspen in Antigonish comitatu Neoscoticorum crescit.

Pileus 1.3-5 cm., depressed, concrescent, whitish, finally light brown, subzonate, center darker; surface radiately ridged, slightly scrobiculate in center; margin thick, then thin, white, elevated, sterile edge often $2 \mathrm{~mm}$. or more wide. Flesh pale brown, thin, (2-3 mm.); odor fungoid, taste farinaceous. Spines up to $3 \mathrm{~mm}$., fine, forked, some tips spathulate, close, grayish-blue with lighter tips, darker towards the stipe, finally dull brownish-gray, slightly decurrent. Stipe $1-5 \times 0.15-0.3 \mathrm{~cm}$., concolorous, obscurely zonate, irregularly flattened and fluted from fusing, expanding upward, arising from a light-brown mycelium. Spores oblong, almost square or with blunt coarse tubercles, 3.5-4.5 $\times 3.4 \mu$.

Gregarious, connate, under spruce on Cape Split. Collection KM 3397 Cape Split, Kings County (DAOM 53377 TYPE). It has a peculiar whitish hoary appearance as it grows. This distinctive small species has been collected for several seasons in the type area and once in Antigonish County. It dries to a brown shade that gives it a close resemblance to a small $H$. scrobiculatum var. zonatum, but, except in outline, has little resemblance to that species when actively growing. The pileus expands very close to the surface of the ground or duff and the stipe varies in length according to the depth of the duff. It does not blacken in $\mathrm{KOH}$.

HYDNELLUM cruentum sp. nov.

(Plate 3, Figure 3)

Pileus 3-10 cm., turbinatus, dilatatus, depressus, concrescens, a tenui crassus, ab albo brunescens, saturans si vulneratus; margine pallidiore, crasso tenuescente, elevato, flaccido, poroso, exsudens guttas rubras; scaber, secundum radios costatus; centrum scrobiculatum; carne pallide brunnea, lilacina, saturata ad basas stipitis, tractata in zonis subcoeruleis; gustu blandus; odor pervasus, medicamentosus (mentholatus?); stipes ad $5 \times 1.5 \mathrm{~cm}$., caesius, attenuatus in radicem albam fragilem; aculeae ad $4 \mathrm{~mm}$., graciles, densae, a lilacinis atrocoerulescentes, deinde lilacine brunneae, pallidiores in apicibus; sporae alutaceae, angulares, cruciatae, cum 4-6 processis crassis, 4-4.5 $\times 3.5-$ 4.5 $\mu$. Rarus, solitarius vel gregarius et connatus, sub Picea in Highland National Park, Cape Breton insulae. Etiam Guysborough et Hants comitatubus. 
Pileus 3-10 cm., club-like, thin or thick turbinate, depressed, expanded, occasionally concrescent, white, pale brown, finally brown, stains darker on bruising; margin lighter colored, very thick becoming thin, elevated, soft and porous, exuding small droplets of red juice; surface rough, scrobiculate at center, radiately ridged with uneven processes. Flesh pale gray to pale brown with tints of lilac, darker downwards in the stem, zonate with bluish bands; taste slight, odor penetrating, medicinal (menthol?) persists slightly in dried specimens. Spines up to $4 \mathrm{~mm}$., close, not or slightly decurrent, lilac to dark blue, finally brown tinted blue, tips lighter. Stipe up to $5 \times 1.5 \mathrm{~cm}$., short, white shaded blue, tapering downward to a white mycelioid brittle root. Spores angular, cruciate, with 4-6 stout processes, 4-4.5 $\times 3.5-4.5 \mu$.

Solitary, gregarious, connate under spruce, Cape Breton Island, Guysborough, Kings, Hants Counties. (I have seen one fragmentary collection from Quebec.) Collection KM 3289 Highland National Park, Cape Breton Island (DAOM $53376 \mathrm{TYPE}$ ). This is a rare species that usually is found as solitary sporophores. Wehmeyer (1940) made collections in Colchester County that were identified as $H$. cyaneotinctum because of the bluish color of pileus and flesh. However, as they were also fragrant, had a rooting stipe and drops of red juice, it is obvious that they should be placed in this species. The type collection was made in moss under spruce in Highland National Park, Cape Breton Island*, where the sporophores were fused and had grown into clumps with concrescent and overlapping pilei. This is a distinctive species that is well marked by the abundance of pale red juice on the young sporophores and growing margins of older plants; the dark blue color of the maturing spines, and the peculiar medicinal odor. Under the microscope the spores are so irregular that some resemble stout metal jackstones. The center of the spines stain lilac when mounted in lactophenol cotton blue and becomes greenish for a short time in $\mathrm{KOH}$. The flesh also turns greenish and fades out.

Hydnellum Geogenium (Fries) Banker, Mycologia 5: 204. 1913.

(Plate 3, Figure 10)

Hydnum geogenium Fries, Vet. Akad. Förh. 131. 1852.

Pilei growing in complicated masses up to $25 \mathrm{~cm}$. across. Individually up to $7 \mathrm{~cm}$., overlapping and concrescent. They arise as clusters of sulphur-yellow columns that expand at the apices and form groups of fused stipes and pilei. In age the pilei are almost black with a greenish shade. Spores subglobose, tuberculate, $3-4.5 \times 3-4 \mu$.

*Found in company with Mr and Mrs. John G. Curtis of the Boston Mycological Club; their nickname of "Bloody Mary," because the sporophores were dripping red juice, inspired the name. 
This is a common species in Nova Scotia under spruce and fir. It is easily recognized by the peculiar sulphur-yellow mycelium, spines and margin. It grows so compact and close to the ground that it appears to be sessile. It often ocurs as solitary sporophores farther south, but has not been seen as such in the province.

Hydnellum Diabolus Banker, Mycologia 5: 194. 1913.

\section{(Plate 3, Figures 7 and 9)}

Hydnellum rhizopes Coker, J. Elisha Mitchell Sci. Soc. 55: 379. 1939. Calodon diabolus (Banker) Snell, Lloydia 19: 166. 1956.

Pileus 2-13 cm., club-shaped, turbinate, convex then plane or depressed, white, then whitish with a dull reddish cast, finally dark brown, surface strigose, matted in age, exuding red droplets when young; margin blunt, whitish becoming brown, staining reddish-brown and darkening on being handled. Flesh spongy, tough, scissile, firmer downward, moist, darkening on exposure; taste acrid, odor strong, sweetish resinous. Spines up to $5 \mathrm{~mm}$., reddish-brown tips lighter, variable in length, fine and close. Stipe dark brown, occasionally blunt, but sometimes tapering downward to a small dark very irregular brittle root with a whitish surface. Spores subglobose to irregular, coarsely tuberculate, 4.5-6 $\times 4-5.5 \mu$.

This is common throughout Nova Scotia and Cape Breton Island and very common on Cape Split where gregarious groups of upwards of 100 sporophores have been found. It is extremely variable in surface texture, coloration and shape, but is constant in the colors of the growing spines and margin of the pileus. The strong resinous odor is distinctive. The acrid taste with a burning sensation in the throat is also present in $H$. peckii.

After seeing the collections of $H$. rhizopes Coker in the herbarium at Chapel Hill, I considered that a number of the Nova Scotia collections of $H$. diabolus were identical with that species. However, as the numbers of collections increased, and the variations were studied it was found that the two species could not be separated and it became apparent that $H$. rhizopes is one of the unusual variations of the extremely variable species $H$. diabolus.

The following is a description of an ecological variation of this species which has been found repeatedly on Cape Split growing under spruce in wet moss and grass. It is so different that at first it was considered a new species. However, in 1955 normal specimens of $H$. diabolus were found in a drier location under adjacent trees and it was recognized as a variation due to the wet habitat. 
Pileus 3-12 cm., irregularly umbonate with depressions, fusing to form large thin sheets with elevated margins, whitish tomentose with red droplets, becoming reddish-brown, grayish-brown to dark brown; margin elevated, white, soon reddish-brown, darkening on being handled; surface tomentose, matting from center outwards and becoming dark brown, scrobiculate or ridged with processes. Flesh light brown to concolorous, very thin, 3-4 $\mathrm{mm}$; odor slight, taste acrid, persistent in the throat. Spines 2-3 mm., fine, close, light brown darkening to brownish-black. Stipe slender, short, tapering to a white mycelioid root. Spore print fawn, spores 5-6 $\times 4-5.5 \mu$.

This is a very striking form with its thin pileus, rough surface and elevated margin, but is identical with the species when young, in odor, taste, color of spines, staining reaction, and markings of spores. This is another instance of the extremes of variation that exist within different species of this genus.

Hydnellum PEckir Banker, Mycologia 5: 203. 1913.

(Plate 3, Figure 8)

Calodon peckii (Banker) Snell \& Dick, in Snell et al., Lloydia 19: 163. 1956.

Pileus 2-15 cm., when fused up to $30 \mathrm{~cm}$., rarely complicate, white then reddish-brown finally grayish-brown, club-shaped at first, then turbinate, convex, plane or depressed, exuding red juice when young; surface tomentose, glabrous in age, smooth or rough; margin tomentose, white, thick then thin, exuding red droplets, staining reddish-brown on being handled. Flesh thick or thin, soft, scissile, tough, firmer downward, light brown then dull brown, faintly zonate with numerous light-colored dots in some collections, staining darker on exposure; taste slowly acrid in throat, odor slight. Spines 3-8 $\mathrm{mm}$., fine, close, tough, white at first, soon reddish-brown, finally reddish-chocolate. Stipe 6-8 $\times 1.5-3 \mathrm{~cm}$., concolorous or darker, outwardly felty tomentose, tapers to a hard white mycelioid root. Spores subglobose, tuberculate, 4.5-5.5 $\times 3.5-4.5 \mu$. Tubercles number 7-9 around the circumference, are rather low and occasionally truncated.

Gregarious, concrescent, growing best in moss under spruce in rather damp locations. It tends to occur under the same trees year after year. It is extremely variable and under wet conditions the plants are greatly expanded and the flesh is thin. Under drier conditions it is small, turbinate and is similar to $H$. diabolus. The two species have similar color changes, red juice, spines and rooting stipe. $H$. peckii differs in the tomentose surface which becomes almost glabrous, in not having a sweetish resinous odor and in having flesh which is thinner, softer and only juicy under wet conditions. 
Hydnellum Mirabile (Fries) Karst., Medd. Soc. Fauna Fl. Fenn. 5: 41. 1879.

\section{(Plate 2, Figure 4)}

Hydnum mirabile Fries, Monogr. Hymen. II: 349. 1863.

Calodon mirabilis (Fries) Karst., Medd. Soc. Fauna Fl. Fenn. 6: 16. 1881.

Pileus 3-14 cm., convex, plane, concave, brownish-white, then khaki to brownish-buff, finally dark brown, white mycelioid where eaten by slugs; margin blunt and thick, may be thin in small specimens, isabelline, gray, darkening when bruised, sterile, exuding coffee-colored drops when young; surface a thick felty layer, strigose, even or roughened and pitted. Flesh duplex, solid, scissile, moist, dull brown, staining darker, zonate, enclosing quantities of twigs and debris; taste slightly acrid in the throat, faint odor. Stipe 1-5 $\times 1-2.5 \mathrm{~cm}$., tapering downward, lighter shade than pileus, dark brownish tomentum, brittle, corky and on breaking exuding a watery yellowish juice that is sweetish, then slightly acrid in the throat. Spines up to $6 \mathrm{~mm}$., stout, close, light brown, then dark brown, tips lighter. Spores subglobose, tuberculate, 5-7 $\times 4.5-6 \mu$.

Solitary, or gregarious in mixed and coniferous woods. The youngest stages found of this species were small irregular pads of strigose honeycolored mycelium exuding coffee-colored drops of juice. The drops dried and darkened the surface. Small projections developed that lengthened and expanded irregularly at the apex to form variously shaped pilei. It took a month for the full development of pilei in 1959. Part of the variability in surface and shape of some sporophores was found to result from irregularities following feeding scars made by slugs. If feeding was stopped while the sporophores were developing, growth continued irregularly in the injured areas and resulted in very irregular shaped sporophores. When the upper surface of the pileus was removed by feeding, a thin layer of white mycelium developed over the surface giving the sporophore the appearance of one of the lighter-colored species.

The original collections made by the author near Kentville were identified by Snell (1954). Additional collections have been made at Glenmont, in Kings County and Aspen, Antigonish County. Wehmeyer (1940) collected this species near Truro and described it in detail. It is characterized by the stout squat manner of growth, the strigose dark brown surface and the watery juice that exudes from a broken stem. It is a species that is very difficult to find but has been collected at Kentville in exactly the same spot every year since 1954.

HYDNELLUM SCROBiculatum (Fries ex Secr.) Karst, var. ScRobiculatum, Medd. Soc. Fauna Fl. Fenn. 5: 41. 1879.

(Plate 2, Figures 7 and 8)

Hydnum cyathiforme a. Bull ex Fries, Syst. Myc. 1: 405. 1821; non H. cyathiforme Schaeff. 1774 . 
Hydnum concrescens Pers., Mycol. Europ. 2: 164. 1825.

Hydnum scrobiculatum Fries ex Secr., Mycogr. suisse 2: 522. 1833.

Pileus 2-7 cm., solitary, connate or in concrescent masses (largest seen was $15 \times 8 \mathrm{~cm}$. in diameter with 5 stipes, and $4 \mathrm{~cm}$. high), solid, convex, plane, depressed; margin rounded, sterile, then thinner and elevated, lobed; surface tomentose, scrobiculate, brown, often zonate and staining dark brown on being handled. Flesh solid and tough, light brown; little or no odor or taste. Spines 1-3 mm., deeply decurrent, concolorous with margin when young, darkening as they mature. Stipe 2-4 cm., concolorous, often fused into flattened or fluted shapes, arising from brown mycelium interwoven with duff. Spores subglobose, tuberculate, 5-6 6 4-5.5 $\mu$. The drops of red juice often reported as occurring on this species have been observed on only two occasions.

Common, solitary, gregarious, connate, concrescent, in coniferous and mixed woods throughout Nova Scotia. The collections used when preparing this description were from the spruce woods at North Alton, where it has been common for years. It occurs in colonies in a variety of forms and sizes, from small pilei $2 \mathrm{~cm}$. in diameter to concrescent masses $15 \mathrm{~cm}$. across. The larger specimens were identical in appearance with Coker and Beers' (1951) Plate 47. The smaller forms appeared identical with his $H$. zonatum. Coker and Beers limited this species to the coarse thick fleshy forms. They also discuss the affinities of other species in this group. The literature has a number of accounts of the difficulties encountered by mycologists in Europe and North America when trying to separate $H$. zonatum and $H$. scrobiculatum. This applies to the Nova Scotia material as well and there does not seem to be any advantage in trying to find a dividing line such as was attempted by Coker and Beers. It is apparent that these species are extremely sensitive to the microclimate around the developing sporophores. It was observed that high humidity and steady temperatures necessary for best growth of the pileus produce a well expanded form that may or may not show zonations and that fluctuating humidity and temperature produce a compact scrobiculate form. Dr. Maas Geesteranus (1957) has boldly grouped these brown hydnums as varieties of $H$. velutinum. This is considered too sweeping a solution because it unites an easily recognized species in which there is only one variation with the most complex series of variations existing in the stipitate hydnums. It is considered desirable to keep $H$. velutinum and its closely related var. spongiosipes (Peck) Maas G. separate and to group H. scrobiculatum and zonatum together. For these reasons we are using $H$. scrobiculatum for practically all our variations and $H$. scrobiculatum var. zonatum for the extremely zonate form usually found under Pinus spp. It is well illustrated by Coker and Beers (1951, Plate 48). 
HYdNELLUM SCROBICUlatum (Fries ex Secr.) Karst. var. zonatum (Batsch ex Fries) comb. nov.

(Plate 2, Figure 9)

Hydnum zonatum Batsch, Elenchus, Contin. sec. 109, pl. 40, fig. 224. 1789; non $H$. zonatum Batsch, Elenchus 111. 1783.

Hydnum cyathiforme b. Fries, Syst. Myc. I: 405. 1821; non $H$. cyathiforme Schaeff. 1774.

Hydnum zonatum Batsch ex Fries, Epicr. Syst. Myc. 509. 18361838.

Hydnellum zonatum (Fries) Karst., Medd. Soc. Fauna Fl. Fenn. 5: 41. 1879.

Hydnellum velutinum var. zonatum (Fries) Maas G., Fungus 27: 64. 1957.

Pileus 3-6 cm., convex, plane, deeply depressed, dull brown, strongly zonate; margin lighter colored, thin, elevated, irregular, darkening on being handled; surface radiately silky, smooth to slightly rough. Flesh thin, firm, tough, scissile, brown; no taste or odor. Spines up to $3 \mathrm{~mm}$, decurrent, light then dull brown, darker brown near stipe, crowded, slender. Stipe up to $4 \mathrm{~cm}$., concolorous, enlarged towards base, arising from a mass of duff and brown mycelium. Spores subglobose, tuberculate, $3-4.5 \times 3-3.5 \mu$.

Gregarious, in pine woods. This is a smaller, thinner variety than $H$. scrobiculatum, and has a light margin. It is not easily separated from collections of thin $H$. scrobiculatum. Coker and Beers (1951) referred a number of their collections of a small southern form found in pine woods to H. parvum Banker, and Wehmeyer (1951) used this name for several of the collections sent to him from the Kentville herbarium. However, after examining the type and the collections at Chapel Hill I decided that the Nova Scotia numbers are small $H$. scrobiculatum and that $H$. parvum probably is not present in the province.

Hydnellum velutinum (Fries) Karst. Medd. Soc. Fauna Fl. Fenn. 5:

41. 1879. var. VELUTINUM.

Hydnum velutinum Fries, Syst. Myc. I: 404. 1821.

Calodon velutinus (Fries) Quél., in Miller and Boyle, Univ. of Iowa Studies Nat. History 18: 65. 1943.

Pileus depressed or umbilicate, dull yellow-brown to fulvous. Harder part of context abruptly separated from softer tissue. Surface remaining dry when handled.

This has not been found with certainty in Nova Scotia but collections from North Carolina and New York have been recognized as this variety by Maas Geesteranus (1957).

For a number of years $H$. velutinum of Europe and $H$. spongiosipes of America have been considered identical, but recently Maas Geesteranus (1957) has separated them as varieties and after a study of them in 
Europe has given a list of distinguishing characteristics for their recognition. The variety spongiosipes is common in Nova Scotia and a certain rare form collected in coniferous woods may be the typical variety. More material is needed before it can be stated definitely.

Hydnellum velutinum (Fries) Karst. var. SPongiosipes (Peck) Maas G., Fungus 27: 62. 1957.

(Plate 2, Figure 10)

Hydnum spongiosipes Peck, Rept. N.Y. State Mus. 50: 111. 1897.

Pileus 3-14 cm., convex, plane to slightly depressed, occasionally fused, light reddish-brown, darkening to deep brown; margin lighter, blunt; surface finely tomentose and irregular taking a finger print and staining red very quickly when bruised, tomentum often collapsing to a smooth layer at center. Flesh concolorous, moist, tough, stringy, with darker brown zones, harder downwards, base of stipe very hard, faint acid odor when young, no distinctive taste. Spines up to $9 \mathrm{~mm}$., light brown on margin, darkening near stem to deep reddish-brown. Stipe $2-7 \times 0.5-2 \mathrm{~cm}$., usually appearing slender for size of pileus, sometimes felted on surface and then thicker, darker than pileus, base light, but may be blackish where it reaches the gray, leached layer under the duff. Spores irregularly globose, tuberculate, 4.5-6 $\times$ 4.5-5.5 $\mu$, tubercles usually blunt, sometimes quite long and stout.

Gregarious, growing in large colonies under red pines on sandy soil at Aldershot and North Williamston. Var. spongiosipes is very resistant to decay and often persists under the pines for more than a year as blackened weatherbeaten bodies too tough to disintegrate readily. Hundreds of fruit bodies have been observed in all stages of growth, but drops of red juice were not observed until 1955, and then only on depressed sporophores after a rain, and in 1959 under very humid conditions on the tops of small young stipes before the pileus had expanded. This species is characterized by the deep brown pileus and spines, and when growing actively, by the lighter colored margin that will take a finger print and quickly stain red on bruising. It is a very different plant than $H$. scrobiculatum. In stature and outline is it very similar to $H$. caeruleum, with which it is often associated.

HYDNELLUM frondosum sp. nov.

(Plate 3, Figure 1)

Formans greges stipitum et pileorum confluentium ad $14 \mathrm{~cm}$, diam.; pileus 1.8-4 cm., convex, depressus, in primis griseus vel griseobrunneus, deinde laete atro-brunnescens, scaber; margine isabellino, tomentoso, pendente, crasso; carne concolore, solida, scissili, atrescente in stipite, subzonata; sine sapore; odor tenuis, medicamentosus; stipites ad $3.5 \mathrm{~cm}$., difformes, rugosi, ad basas connati, atro-brunnei, ad basas nigrescentes; aculeae ad $1 \mathrm{~mm}$., decurentes, numerosissimae, graciles, 
in primis pallido-brunneae, deinde ad basas atro-brunneae et ad summas pallidiores; sporae alutaceae, a globosis oblongae, tuberculatae, $3.5-4.5 \times 3-4 \mu$. Rarus, solitarius, apud Pinos et Tsugas prope pagum Kentville. Leniter crescens.

Pileus 1.8-4 cm. when young, develops to gray masses of overlapping pilei, up to $14 \mathrm{~cm}$. across, convex, depressed, grayish-brown when young, finally mousy-brown with broad whitish margin; surface rough; margin isabelline, soft, taking a finger print, drooping, thick, irregular. Flesh concolorous with surface, fibrous, darker brown in stipe, slightly zonate, no taste, slight medicinal odor. Spines up to $1 \mathrm{~mm}$., deeply decurrent, close and slender, brownish white changing to deep brown with lighter tips. Stipes up to $3.5 \mathrm{~cm}$., connate, tapering downwards to a compact thick rooting base, dark brown and blackening in the soil; surface uneven and rough. Spores globose to oblong, tuberculate, 3.5-4.5 $\times 3-4 \mu$. Spore print fawn.

Growing near pine and hemlock in mixed woods. Collection KM 2362 Ravine, Kentville Research Station, Kings County (DAOM 53374 TYPE). It matures very slowly. A very firm and compact plant that does not shrink on drying. This is a distinct species, difficult to describe adequately. When young plants of this species were first collected there was some difficulty in connecting them with the mature stages. They are solid, gray columns that have little resemblance to mature specimens.

\section{HYDNELLUM multiceps sp. nov.}

(Plate 3, Figure 4)

Formans greges stipitum et pileorum confluentium ad $30 \mathrm{~cm}$. diam., et $8 \mathrm{~cm}$. alt.; pileus $3-5 \mathrm{~cm}$., rugosus, radialiter corrugatus, zonatus, in primis pallide brunneus, deinde atro-brunneus; ad centrum minute scrobiculatus; margine crasso, tenuante, elevato vel imbricato depressoque, albo, sterili; carne 1-2 $\mathrm{mm}$., fibrosa, fragili, densiore in corde stipitis, isabellina, in primis griseo-brunnea, deinde atro-brunnea; sine gustu, pariter odore; stipes 2-3 $\times$ 0.4-0.6 cm., ad summas incrassatus, pallide brunneus, tomentosus, connatus, cavernis spinularum vestitis; aculeae $2.5 \mathrm{~mm}$., majores versus stipitem, conspicure decurrentes, isabellinae, in primis griseo-brunneae, deinde atro-brunneae, graciles, numerosissimae; sporae alutaceae, subglobosae, tuberculatae; tuberculis acutis, $3-4.5 \times 3-4 \mu$.

Rarus, solitarius, vel gregarius, vel circinans in Piceetis, apud Glenmont, Kings comitatu, atque in insula Cape Breton dicta.

Pileus 3-5 cm., fused into masses of stipes and closely overlapping pilei up to $30 \mathrm{~cm}$. across and $8 \mathrm{~cm}$. high, radiately ribbed beneath; surface rough, radiately ridged, center finely scrobiculate, zonate, pale brown becoming dark brown; margin thick, then thin, elevated, or overlapping and depressed undulating, whitish, sterile. Flesh 1-2 mm., pale brown, soft, fibrous, brittle, neither taste nor odor. Spines 2-5 $\mathrm{mm}$., isabelline, grayish-brown, finally dark-brown, fine, close decurrent to base of some stipes, longest on stipe near the ground. Stipe $2-3 \times 0.4-0.6 \mathrm{~cm}$., expanding 
upwards, light brown and tomentose on exposed surfaces, flesh brittle with a hard core. In the larger clumps the stipes are fused into an intricate tangle with numerous cavities lined with spines. Spore print alutaceous, spores subglobose, tuberculate, processes rather sharp, 3-4.5 $\times 3-4 \mu$.

Collection KM 2359, Glenmont, Kings County, (DAOM 53379 TYPE).

This grows very luxuriantly in the spruce woods in Glenmont, Kings County where it was once found as a partial fairy ring some $20 \mathrm{ft}$. in diameter. It was collected in 1956 on Cape Breton Island. It also occurs as small individual pilei with the typical white margin and light colored spines. This species differs from $H$. zonatum and $H$. scrobiculatum in the pale color of the young mycelium, the whitish margin, the whitish young spines that change very slowly, the lighter colored rather brittle flesh and the peculiar ribbed effect of the lower surface. The flesh at the base of the spines blackens in $\mathrm{KOH}$.

Steccherinum S. F. Gray, Nat. Arr. Brit. Plants 1: 651. 1821.

Sporophores laterally pileate from a base, or dimidiate flabelliform, or rarely sessile, usually tough and fibrous, sometimes subfleshy. Spines terete or flattened, cystidia common, spores minute, finely roughened or smooth, white in mass. Growing on wood. Only two species have been recognized in Nova Scotia though it is probable that others will be found as several are known to be widely distributed.

\section{Steccherinum Septentrionale (Fries) Banker, Mem. Torrey Bot.}

Club 12: 130. 1906.

Hydnum septentrionale Fries, Syst. Myc. I: 414. 1821.

Sporophore massive, imbricated, $60 \times 30 \mathrm{~cm}$. and $15 \mathrm{~cm}$. deep, growing from a solid fleshy base, individual pilei up to $30 \times 20 \mathrm{~cm}$; surface rough, fibrous, white, later yellowish; margin thick becoming thin, incurved. Flesh white, juicy when young, tough, fleshy; odor yeasty when young, no taste. Spines up to $2 \mathrm{~cm}$., white then yellow, crowded, slender tough. Spores smooth, ellipsoid, 4.5-5.5 $\times 2.5 \mu$. Cystidia stout 12-18 $\mu$ thick.

The first collection made was spotted on the side of a large maple tree near Kentville by Dr. J. Walton Groves in 1953. It was collected by using a ladder and chopping it out of a crevice with an axe, but was too large to be kept intact. A smaller specimen was found in Canard, Kings County, on maple in 1954.

Steccherinum ochraceum (Pers. ex Fries) S. F. Gray, Nat. Arr. Brit.

Plants 1: 651. 1821.

Hydnum ochraceum Pers. ex Fries, Syst. Myc. I: 414. 1821. Hydnum rhois Schw., Schr. Nat. Ges. Leipzig I: 103. 1822. 
Sporophores resupinate to reflexed, or pileate and laterally sessile, fibrous, tough; surface soft, tomentose, sulcate-zoned; margin whitish, pilose. Spines up to $2 \mathrm{~mm}$., crowded, slender, light orange to orange. Spores hyaline, smooth, obovate, 3-4 $\times 2-2.5 \mu$.

This species is rare in Nova Scotia and has been collected by the author in the resupinate condition three times, and in the pileate once. Collections have been reported by Wehmeyer (1951) from Colchester County.

Hericium Pers. ex S. F. Gray, Nat. Arr. Brit. Plants 1: 652. 1821.

Dryodon Quélet, in Cooke and Quélet, Clav. Hymen. 198. 1878. Manina Scop. ex Banker, Mycologia 4: 275. 1912.

Sporophore fleshy, in masses on sides of trees; nodular or branched. Spines subulate, pendent. Spores white, subglobose, smooth or minutely roughened. Growing on wood. This genus was once common on beech logs but since most of the host trees have been destroyed by the beech coccus there is no longer a favorable substrate for this genus in the province.

\section{Key to THE GENUS HeRICIUM IN NOva Scotia}

A. Sporophore a mass. Spines very long, up to $4 \mathrm{~cm}$.

H. erinaceus

B. Sporophore branched. Spines short, up to $5 \mathrm{~mm}$.

a. Branches intricate and fused. Spores subglobose. H. ramosum

b. Main branches stout. Spines longer. Spores globose. H. coralloides

Hericium erinaceus (Bull. ex Fries) Pers., Myc. Europ. 2: 153. 1825.

Hydnum erinaceus Bull. ex Fries, Syst. Myc. I: 407. 1821.

Manina cordiformis Scop. ex Banker, Mycologia 4: 277. 1912.

Sporophore solid or porous, soggy, $4 \times 8 \mathrm{~cm}$., growing from a tough tubercular attachment on wood. Covered with long pendulous spines up to

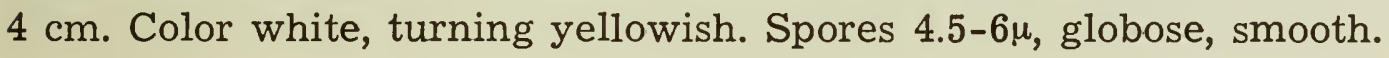

This is a rare species in Nova Scotia and the only collection by the author is a small specimen found on the end of a birch log near Kentville. It is usually reported as growing much larger. Previously reported from Antigonish County by MacKay (1904).

Hericium Ramosum (Bull. ex Mérat) Letellier, Hist. Descr. Champ. 43. 1826.

Hydnum coralloides Scop. ex Fries, Syst. Myc. I: 408. 1821, in part. Hericium laciniatum Leers ex Banker, Mem. Torrey Bot. Club 12: 114. 1906.

Manina flagellum Scop. ex Banker, Mycologia 4: 276. 1912.

Sporophores branched repeatedly, fused, growing from a tough attachment on wood, pure white with tinge of cream. Spines short and 
pendent from the branches, up to $5 \mathrm{~mm}$., pure white, later tinged with cream as they mature. Spores subglobose, 3.5-4 $\times$ 4-5.5 $\mu$. Collected on end of a beech log. A very beautiful delicate species with many fine branches covered with spines.

Hericium coralloides (Scop. ex Fries) S. F. Gray, Nat. Arr. Brit Plants 1: 652.1821.

Hydnum coralloides Scop. ex Fries, Syst. Myc. I: 408. 1821, in part.

Sporophores branched, from a tough attachment on wood. Spines pendent from the ends of branches, up to $15 \mathrm{~mm}$., pure white and turning

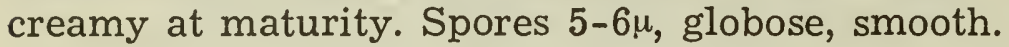

Miller and Boyle (1943) have discussed the relationship between $H$. laciniatum, (H. ramosum) and $H$. coralloides. 


\section{Acknowledgments}

I am indebted to Prof. D. P. Rogers for permission to examine collections of hydnums at the New York Botanical Garden; to Prof. J. N. Couch, the W. C. Coker collections at Chapel Hill; to Dr. MacKenzie Lamb, the collections in the Farlow Herbarium; to Prof. A. H. Smith, the collections in the herbarium, University of Michigan; to Prof. R. P. Korf, the collections in the herbarium, Cornell University; to Prof. W. H. Snell of Brown University for advice and identification of early collections; to Dr. J. Walton Groves for reading this paper and for advice on various problems arising during the course of these studies; to I. L. Conners for painstakingly checking the final draft and making a number of very helpful suggestions regarding the synonymy of different species; to Dr. Bernard Boivin for making the Latin translations of the descriptions of the new species; and to Mr. and Mrs. John G. Curtis who first drew my attention to the abundance of hydnums on Cape Breton Island and then took me on two forays to their favorite collecting areas. 


\section{Plate 1}

Fig. 1. Phellodon niger var. niger

2. Phellodon niger var, alboniger

3. Phellodon melaleucus

4. Phellodon tomentosus

5. Bankera fuligineo-alba

6. Bankera carnosa

7. Hydnum scabrosum, young

8. Hydnum scabrosum, mature

9. Hydnum imbricatum

10. Hydnum lanuginosum 


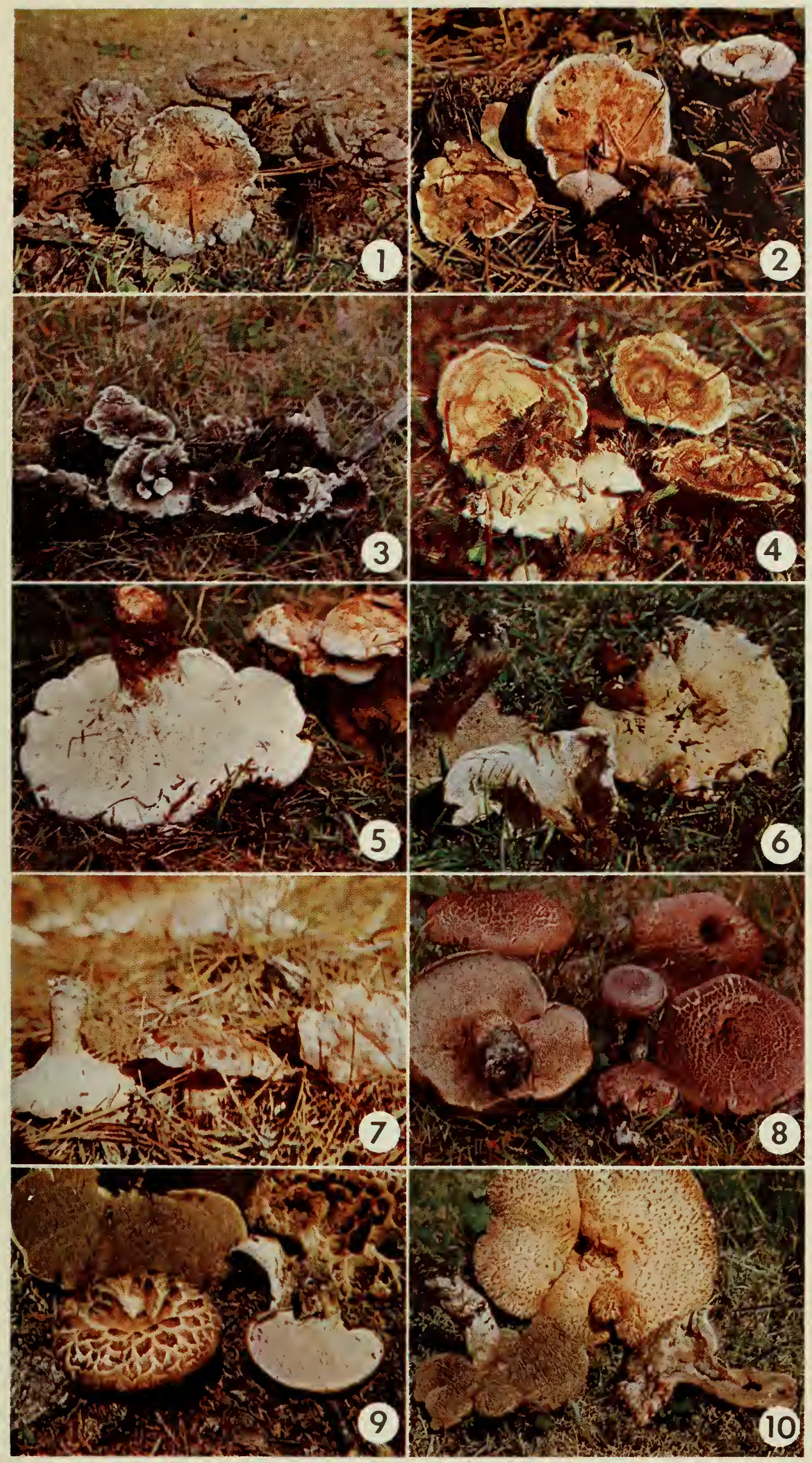




\section{Plate 2}

Fig. 1. Hydnum stereosarcinon

2. Hydnum subfelleum

3. Hydnum crassum

4. Hydnellum mirabile

5. Hydnellum caeruleum

6. Hydnellum suaveolens

7. Hydnellum scrobiculatum, stout form

8. Hydnellum scrobiculatum, thin form in bracken

9. Hydnellum scrobiculatum var. zonatum, from under Pinus resinosa

10. Hydnellum velutinum var. spongiosipes 


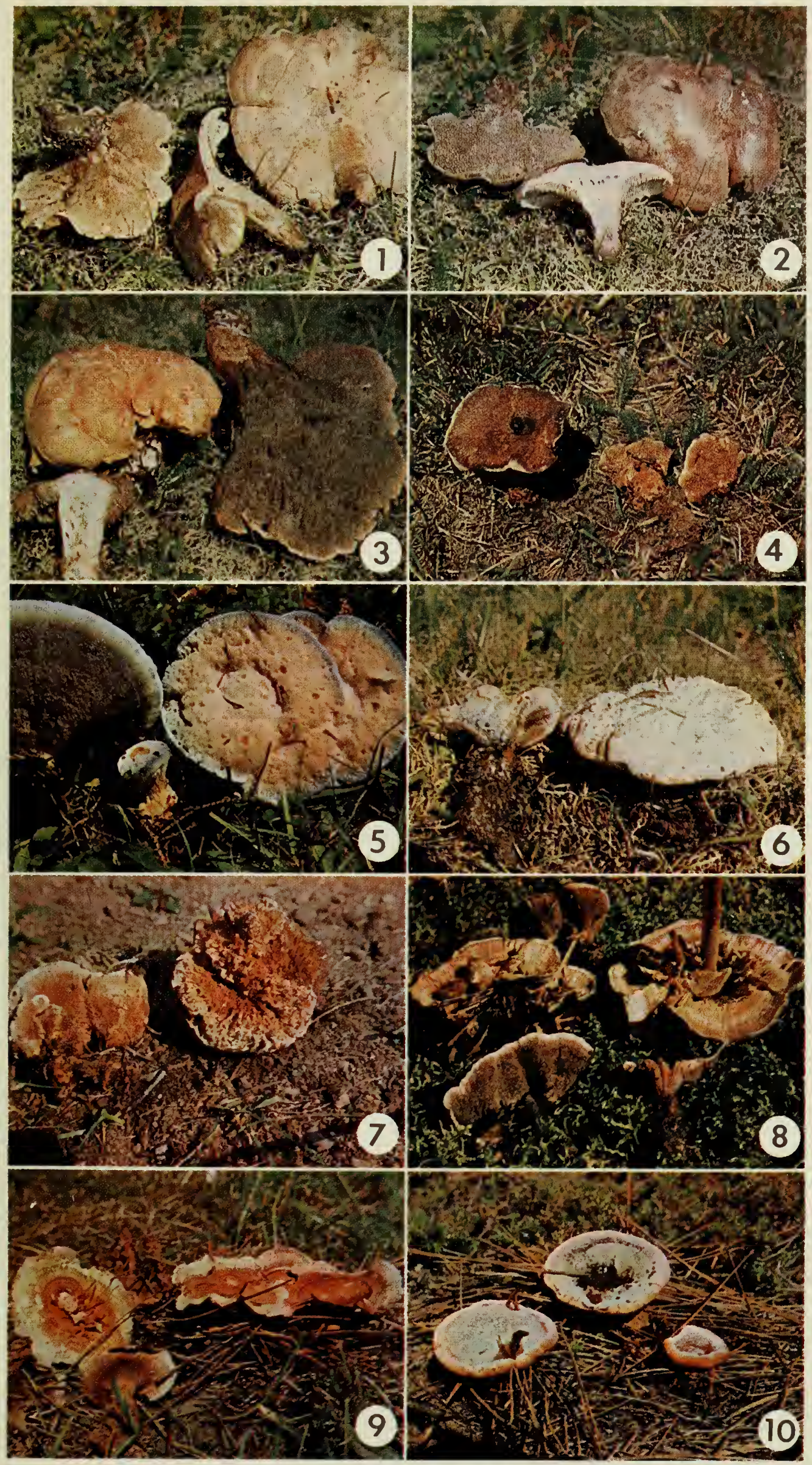




\section{Plate 3}

Fig. 1. Hydnellum frondosum

2. Hydnellum subzonatum

3. Hydnellum cruentum

4. Hyảnellum multiceps

5. Hydnellum aurantiacum, a variation

6. Hydnellum aurantiacum

7. Hydnellum diabolus, thin form

8. Hydnellum peckii, stout form

9. Hydnellum diabolus

10. Hydnellum geogenium 


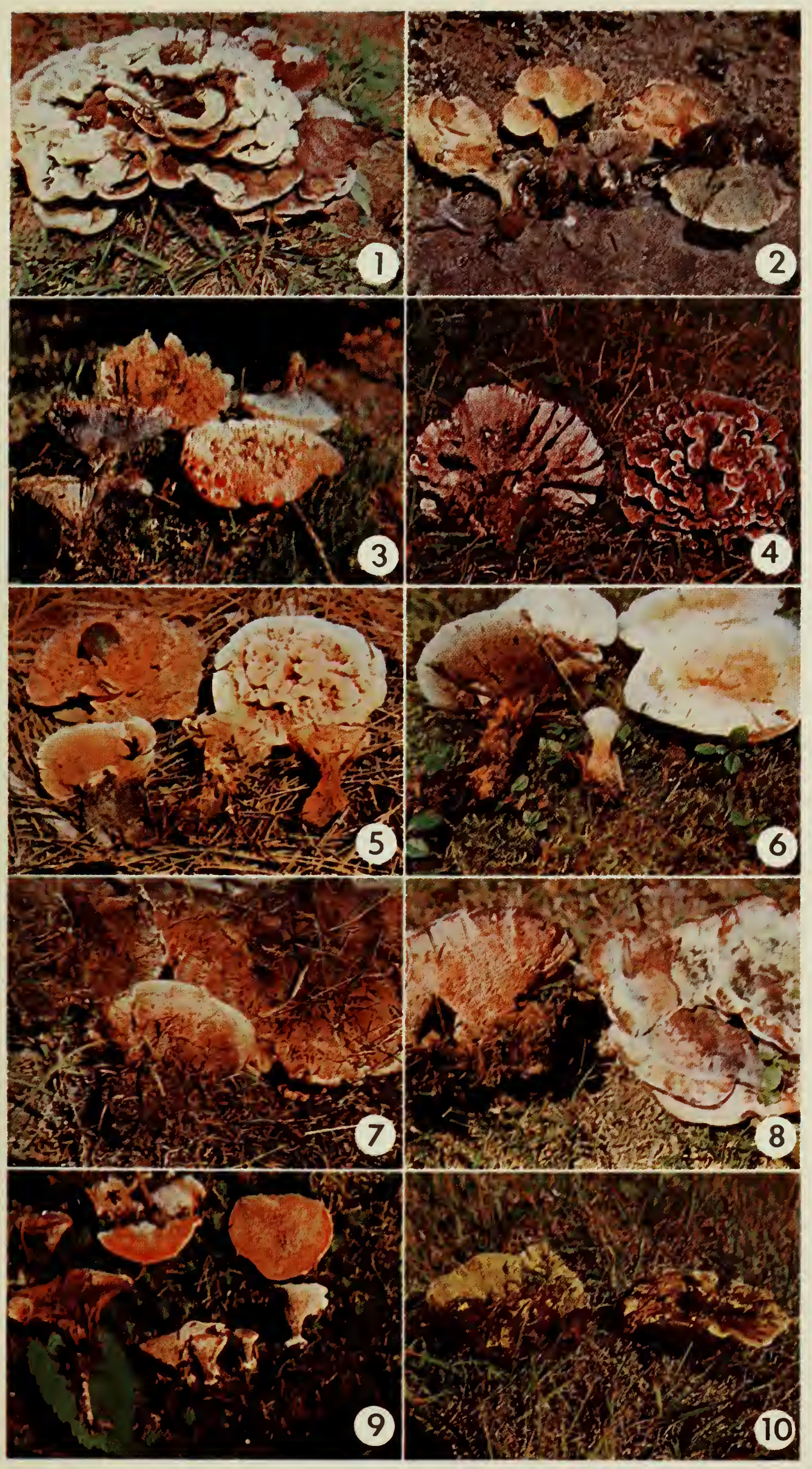





\section{Literature Cited}

Banker, H. J. 1906. A contribution to a revision of the North American Hydnaceae. Mem. Torrey Bot. Club 12: 99-194.

Bresadola, J. 1932. Iconographia mycologica. 21: pls. 1035-1050; 22: pls. 10511060.

Coker, W. C., and A. H. Beers. 1951. The stipitate hydnums of the eastern United States. Univ. N.C. Press, Chapel Hill.

Cooke, M. C., and L. Quélet. 1878. Clavis synoptica hymenomycetum Europaeorum. London.

Donk, M. A. 1933. Revision der niederlandischen Homobasidiomycetae-Aphyllophoraceae Teil II. In Med. Nederl. Mycol. Ver. 22.

Donk, M. A. 1956. The generic names proposed for Hymenomycetes. V. Taxon 5: 69-80, 95-115.

Gray, S. F. 1821. Natural arrangement of British plants. London.

Harvey, R. 1958. Sporophore development and proliferation in Hydnum auriscalpium Fries. Trans. Brit. Mycol. Soc. 41: 325-334.

Karsten, P. A. 1879. Symbolae ad mycologiam Fennicum. Medd. Soc. Fauna Fl. Fenn. 5: 40-42.

Karsten, P. A. 1881. Enumeratio Hydnearum Fr. Fennicarum systemata novo dispositarum. Revue Mycologique 3: 19-21.

Lloyd, C. G. 1922. Note 1128. Mycological Notes 7: 1166.

Maas Geesteranus, R. A. 1956. The stipitate hydnums of the Netherlands. I. Sarcodon P. Karst. Fungus 26: 44-60.

Maas Geesteranus, R. A. 1957. The stipitate hydnums of the Netherlands. II. Hydnellum P. Karst. Fungus 27: 50-71.

Maas Geesteranus, R. A. 1958. The stipitate hydnums of the Netherlands. III. Phellodon P. Karst. and Bankera Coker \& Beers ex Pouz. Fungus 28: 48-61.

Maas Geesteranus, R. A. 1959. The stipitate hydnums of the Netherlands. IV. Auriscalpium S. F. Gray, Hericium Pers. ex S. F. Gray, Hydnum L. ex Fr. and Sistotrema Fr. em. Donk.

MacKay, A. H. 1904. Fungi of Nova Scotia: a provisional list. Proc. and Trans. N. S. Inst. of Sci. 12: 119-138.

Michael, E., and R. Schulz. 1927. Führer für Pilzfreunde Vol. 3: pl. 266-386. Leipzig, Quelle und Meyer.

Miller, L. W., and J. S. Boyle. 1943. The Hydnaceae of Iowa. Univ. Iowa Studies in Nat. History 18: 1-92. 
Nichols, G. E. 1935. The hemlock-white pine-northern hardwood region of eastern North America. Ecology 16: 403-422.

Putnam, D. F. 1940. The climate of the Maritime Provinces. Can. Geog. Jour. 21: $135-147$.

Quélet, L. 1886. Enchiridion Fungorum in Europa media, 188-193. Lutetiae.

Rea, Carleton. 1922. British Basidiomycetae. Cambridge.

Roland, A. E. 1947. The flora of Nova Scotia. Proc. Nova Scotian Inst. Sci. 21: part 3, 1-552.

Snell, W. H. 1945. Notes on the pileate hydnums. Mycologia 37: 46-52.

Snell, W. H., and Henry A. C. Jackson, 1954. Notes on the pileate hydnums. II. Lloydia 17: 247-256.

Snell, W. H., Esther A. Dick, Henry A. C. Jackson, and Marguerite Taussig. 1956. Notes on the pileate hydnums. III. Lloydia 19: 163-175.

Snell, W. H., and Esther A. Dick. 1958. Notes on the pileate hydnums. IV. Lloydia 21: 34-37.

Wehmeyer, L. E. 1940. Contributions to the study of the fungus flora of Nova Scotia IV. Can. J. Research, C. 18: 92-110.

Wehmeyer, L. E. 1951. The fungi of New Brunswick, Nova Scotia and Prince Edward Island. National Research Council, Ottawa. 


\section{Index of Genera and Species}

[A main entry is in bold-faced type]

Auriscalpium S. F. Gray 18

auriscalpium (L. ex Fries) Banker 18

vulgare S. F. Gray 18, 21

Bankera Coker \& Beers ex Pouzar 24; Key to, 20

carnosa (Banker) Snell, Dick \& Taussig 15, 17, 25

fuligineo-alba (Schmidt ex Fries) Pouzar 15, 17, 24

Calodon Quélet 16, 31

alboniger (Peck) Seeler 22

amicus Quél. 23

cyathiformis Quél. 20

diabolus (Banker) Snell 39

mirabilis (Fries) Karst. 41

niger Quél. 22

peckii (Banker) Snell \& Dick 40

velutinus (Fries) Quél. 43

Dentinum S. F. Gray 18

albidum (Peck) Snell 19

repandum (Fries) S. F. Gray 29

var. album (Quél.) K. Harrison 19

var. repandum 19

umbilicatum (Peck) Pouzar 19

\section{Dryodon Quélet 47}

Hericium Pers. ex S. F. Gray 47; Key to, 47

coralloides (Scop. ex Fries) S. F. Gray 48

erinaceus (Bull. ex Fries) Pers. 47 laciniatum Leers ex Banker 47, 48

ramosum (Bull. ex Mérat) Letellier 47, 48

Hydnaceae, Key to, 17

Hydnellum Karsten 31; Key to, 32 aurantiacum (Batsch ex Fries) Karst. $12,14,15,34,35,36$

caeruleum (Hornemann ex Pers.)

Karst. 13, 14, 15, 33, 34

complicatum Banker 36

conigenum (Peck) Banker 36

cruentum K. Harrison 15, 34, 37 cyaneotinctum (Peck) Banker 33, 34, 38

diabolus Banker 15, 39, 40

earlianum Banker 36

ferrugipes Coker 34, 36

frondosum $\mathrm{K}$. Harrison 44

geogenium (Fries) Banker 13, 38

mirabile (Fries) Karst. 15, 41

multiceps $\mathrm{K}$. Harrison $\mathbf{4 5}$

nigrum Karst. 22

parvum Banker 43

peckii Banker 15, 39, 40

rhizopes Coker 39

rickerii Banker 33

scrobiculatum (Fries ex Secr.) Karst.

$13,15,31,42,43,46$

var. scrobiculatum 41

var. zonatum (Batsch ex Fries) K. Harrison 37, 43

sauveolens (Scop. ex Fries) Karst. $13,14,33$

subzonatum K. Harrison $\mathbf{3 7}$

velutinum (Fries) Karst. 43

var. spongiosipes (Peck) Maas G. $14,15,31,42,44$

var. velutinum 42,43

var. zonatum (Fries) Maas G. 42, 43

zonatum (Fries) Karst. 43, 46

Hydnum Fries 18, 25; Key to, 26

albidum Peck 19

albonigrum Peck 22

amarescens Quél. 28, 29

amicum Quél. 23

aurantiacum Alb. \& Schw. 34

auriscalpium Fries 18, 21

boreale Banker 33

brevipes (Coker) Snell 30

brevipes Opiz 30

caeruleum Hornemann ex Pers. 33

carnosum (Banker) Trotter 25

concrescens Pers. 42

confluens Pers. 23

coralloides Scop. ex Fries 47, 48

coriaceo-membranaceum Schw. 20

crassum K. Harrison 29 
cristatum Bres. 31

cyaneotinctum Peck 33

cyathiforme $a$ Bull. ex Fries 41

cyathiforme $b$ Bull. ex Fries 43

erinaceus Bull. ex Fries 47

fennicum (Karst.) Sacc. 27

floriforme Schaeff. 34

fragile Fries 24, 25

fuligineo-album Schmidt 24

fuligineo-album Fries 24

geogenium Fries 38

graveolens Delastre in Fries 21

graveolens subzonatum Peck 20

imbricatum Fries 17, 27, 28

lanuginosum $K$. Harrison 15, 30

melaleucum Fries 20, 21

mirabile Fries 31, 41

nigrum Fries 22

ochraceum Pers. ex Fries 46

repandum Fries 16, 19

var. album (Quél.) Rea 19

roseolum (Banker) Snell 28

rhois Schw. 46

scabrosum Fries 26, 27, 28

scrobiculatum Fries ex Secr. 42

septentrionale Fries 46

spongiosipes Peck 43, 44

stereosarcinon (Wehmeyer) K. Har-

rison $15,29,30,31$

suaveolens Scop. ex Fries 33

var. caeruleum Fries 33

subfelleum K. Harrison 28, 29, 30

sublamellosum Bull. 18

tomentosum Fries 20

umbilicatum Peck 19

vellereum Peck 23

velutinum Fries 43

zonatum Batsch ex Fries 42, 43

Hypothele Paulet ex Banker 18

Manina Scop. ex Banker 47 cordiformis Scop. ex Banker 47 flagellum Scop. ex Banker 47
Polyporus confluens Alb. \& Schw. ex Fries 29

frondosus Dicks. ex Fries 14

Phellodon Karsten 19; Key to, 20

alboniger (Peck) Banker 22, 23

amicus (Quél.) Banker 22, 23

carnosus Banker 25

confluens (Pers.) Pouz. 22, 23

cyathiformis Karst. 20

ellisianus Banker 20, 21

graveolens (Delastre in Fries) Banker 21, 22

melaleucus (Fries) Banker 20, 21, 22

niger (Fries) Karst. 13, 15, 22, 23 var. alboniger (Peck) $\mathrm{K}$. Harrison 15, 22, 23

var. niger 15, 22, 23

tomentosus (Fries) Banker 13, 20

vellereus (Peck) Banker 24

Sarcodon Karsten 25

brevipes Coker 30

cristatus (Bres.) Banker 31

fennicus (Karst.) Karst. 27

imbricatus (L. ex Fries) Karst. 28

murrillii Banker 27

radicatus Banker 28

repandus (Fries) Quél. 19

var. albus Quél. 19

roseolus Banker 28

scabrosus (Fries) Karst. 26

var. fennicus Karst. 27

stereosarcinon Wehmeyer 30

underwoodii Banker 27

Sistotrema Fries 18

confluens Pers. ex Fries 18

Steccherinum S. F. Gray 46 ochraceum (Pers. ex Fries) S. F. Gray 46

septentrionale (Fries) Banker 46

Tydrodon Karsten 18 repandus (Fries) Karst. 19 


$$
\text { . }
$$



